\title{
Rent Withholding for Welfare Recipients: An Empirical Study of the Illinois Statute
}

In 1965, Illinois adopted legislation ${ }^{1}$ designed to improve housing conditions of public aid recipients and to end state subsidization of slum housing. The statute authorized the state public aid department to withhold rent allowances from public aid recipients living in substandard buildings and established a defense for recipients against eviction while rent is being withheld. This study will examine the effectiveness of this statute as applied by the Cook County Department of Public Aid. ${ }^{2}$

\section{General Structure of Rent Withholding}

This section will examine the judicial and legislative remedies available to tenants in general and will then focus briefly on the specific Illinois experience with rent withholding prior to its passage of the 1965 Act.

Historically, the common law provides few remedies to the tenant faced with deteriorating housing. ${ }^{3}$ Though the tenant has a right to possession, his landlord has no obligation to maintain the premises in habitable condition. Further, since the covenants in a lease are independent of each other, ${ }^{4}$ even if the landlord is required by covenant or statute to make repairs, his failure to do so generally will not excuse the tenant from paying rent. ${ }^{5}$

This body of law developed in a period when long term leases for large tracts of land were typical, and the tenant's primary purpose was to

1 Ill. Rev. Stat. ch. 23, § 11-23 (1969).

2 The study was conducted from December, 1969 through February, 1970 at the Central Office of the Cook County Department of Public Aid, Chicago, Illinois. The data is on file at the University of Chicago Law Revicw office. The authors wish to thank David $L$. Daniel, Director, Cook County Department of Public Aid, and Victor Spallone, Chief, Bureau of Housing, and their staffs for their cooperation and assistance. The authors also wish to express special thanks to Miss Nancy Singleton, of the Department's Research and Statistics Division, for her invaluable advice concerning collection of the data.

3 See Schoshinski, Remedies of the Indigent Tenant: Proposal for Change, 54 Gro. L.J. 519 (1966).

4 Id.

5 Simmons, Passion and Prudence: Rent Withholding under New York's Spiegel Law, 15 Buffalo L. Rev. 572, 575 (1969); 1 American Law of Property § 3.78 (A.J. Casner ed. 1952). 
obtain profits from the use of the land. ${ }^{6}$ The common law considered the tenant the possessory owner of an estate for years, and the primary indicia of ownership passed to him. ${ }^{7}$ Today, however, most leases for low income housing are short term and are meant only to provide living quarters for the tenant. The tenant is more concerned with habitability than with the possibility of landlord interference with his possession. 8

The courts have developed two private remedies to force the landlord to repair, but they are of limited assistance to the low income tenant. ${ }^{9}$ The first remedy is the constructive eviction doctrine, which excuses the tenant's rent obligations when the landlord has allowed the premises to become so dilapidated that he can be said to have interfered with the tenant's use of the leasehold property. To claim a constructive eviction, however, the tenant must move within a reasonable time. ${ }^{10}$ The inadequacies of the doctrine for the low income tenant are obvious. The tenant can never be certain before a judicial determination whether the doctrine applies to his building. More importantly, the tenant must move in order to invoke the doctrine, an undesirable alternative if the supply of low income housing is low and the cost and disruptive effects of relocation are high. ${ }^{11}$ In the case of a thirty-day lease, for example, the tenant would save only one month's rent by moving, which would usually be offset by the cost and inconvenience involved.

The second judicial remedy is the partial eviction doctrine. If the tenant is deprived of some portion of the premises before or during occupancy, he is relieved of paying rent until he gains access to the entire premises. ${ }^{12}$ The deprivation or ouster must be accomplished by a physical act of the landlord; judicial interpretation has not yet extended the doctrine to cover constructive eviction from only a portion of the premises. ${ }^{13}$ The strictness of interpretation has thus ren-

( Comment, Rent Abatement Legislation: An Answer to Landlords, 12 VirL. L. REv. 631 (1967).

7 Comment, Rent Withholding and the Improvement of Substandard Housing, 53 Caur. L. REv. 304, 311 (1965) [hereinafter cited as Comment, Rent Wilhholding]; 1 AMErucaN LAW of ProperTy, supra note 5, at § 3.38.

8 Comment, Rent Abatement Legislation: An Answer to Landlords, supra note 6.

- A third remedy has been developed more recently, see notes 14-17 and accompanying text supra.

10 Dyett v. Pendleton, 8 Cow. (N.Y.) 727 (1826); Rapacz, Origin and Evolution of Constructive Eviction in the United States, 1 DE PAuL L. REv. 69 (1951).

11 Note, Enforcement of Municipal Housing Codes, 78 HARv. L. REv. 801, 844 (1965). 12 Fifth Avenue Building Co. v. Kernochan, 221 N.Y. 370, 117 N.E. 579 (1917); Simmons, supta note 5, at 577-8; 1 AMERICAN LAW OF PROPERTY, supra note 5, at § 3.52 .

13 Gombo v. Martise, 44 Misc. 2d 239, 253 N.Y.S.2d 459 (Sup. Ct. 1964), rev'g 41 Misc. 
dered the partial eviction doctrine of little assistance to the low income tenant.

The Court of Appeals for the District of Columbia Circuit has recently developed a third remedy, which seems to provide judicial authorization for private rent withholding. ${ }^{14}$ The court held that a tenant may be excused from paying all or part of his rent if the landlord breaches, in whole or in part, his implied warranty of habitability. ${ }^{15}$ This warranty arises out of the landlord's duty, under the housing codes, to keep the premises in habitable condition. ${ }^{16}$ If the tenant can establish breach of warranty, he can withhold rent and continue in possession, presumably until the landlord makes the necessary repairs. ${ }^{17}$ While the far-reaching implications of this decision are unexplored and the standards the courts will use in determining breach of warranty are still nebulous, this remedy goes further than either the constructive or partial eviction doctrines in providing an economic inducement for repair while giving the tenant a right to continued possession.

In the area of state legislation, the trend in the past two decades has been toward the development of integrated housing codes regulating structural soundness, fire protection, maintenance, sanitation and occupancy. Adopted in over 650 cities since 1954,18 these codes place the burden of maintenance and repair on the landlord. ${ }^{19}$ How-

2d 475, 246 N.Y.S.2d 750 (Civ. Ct. N.Y. 1964); Simmons, supra note 5, at 575; Schoshinski, supra note 3 , at 531 .

14 Javins v. First Nat'l Realty Corp., 38 U.S.L.W. 2596 (D.C. Cir., May 7, 1970), rev'g Saunders v. First Nat'l Realty Corp., 245 A.2d 836 (D.C. App. 1968).

15 The court said that principles of modern contract law rather than principles of real property law should apply to leases of urban apartment dwellers. The expectations of the tenant in signing the lease are analogized to that of an ordinary consumer. The lessor is selling a "package of goods and services that include ... adequate heat, light and ventilation, proper sanitation and proper maintenance." 38 U.S.L.W. at 2596.

16 The court in this jurisdiction had earlier held that the landlord had a contractual duty under the lease to correct violations known to exist at the time the lease was signed. The theory was that the lease was an illegal contract because it was made in violation of a statutory provision designed for regulatory or police purposes (i.e., the housing code) and therefore conferred no right on the wrongdoer (Iandlord). Brown v. Southall Realty Co., 237 A.2d 834 (D.C. App. 1968). The Javins case extends this theory to cases where the violations arose after the lease was signed, by holding that the housing code imposes a duty on the landlord to keep the premises in habitable condition.

17 The jury may find that only part of the tenant's obligation to pay rent has been suspended because the landlord's breach was not total. The tenant will be permitted to remain in possession, however, as long as he pays as much of the rent as the jury stipulates.

18 The Housing Act of 1954, 68 Stat. 590, required as a precondition for urban renewal funds that any city applying for such funds have a plan for code enforcement. Note, Enforcement of Municipal Housing Codes, supra note 11, at 803.

$19 I d$. at 810 . 
ever, most codes suffer from a number of administrative problems, such as lack of adequate administrative machinery, overlap in the jurisdictions of enforcement agencies, and lack of adequate penalties for noncompliance. Further, enforcement agencies often have not attempted to force strict adherence to the codes because they fear such enforcement may cause landlords either to raise the rent substantially or to vacate the buildings, thereby forcing low income tenants to seek other housing accommodations in a shrinking low income housing market. ${ }^{20}$ These difficulties, which were dramatized by a series of well publicized private rent strikes in the early 1960's, led a number of states to enact rent.withholding legislation. ${ }^{21}$ At the present time, nine states have private rent withholding statutes authorizing the tenant to withhold, ${ }^{22}$ and two states have public rent withholding statutes authorizing the public aid department to withhold rent allowances from public aid recipients and landlords. ${ }^{23}$

Prior to the adoption of the public rent withholding statute in 1965, rent withholding in Illinois was effected by administrative action rather than by statute. In August, 1961, the Cook County Department of Public Aid (hereinafter referred to as the CCDPA or the Department) ${ }^{24}$ began withholding rent allowances from public aid recipients living in dwellings which did not meet the minimum standards pre-

20 Comment, Rent Withholding, supra note 7, at 316-20, 322.

21 In 1963 and 1964, slum dwellers in several large cities initiated a number of rent strikes in order to force the landlords to maintain the property in accordance with housing, health and safety codes. Many of the strikes were not only successful in accomplishing their immediate goal of inducing the landlord to make repairs, but also had the more far-reaching effect of increasing pressure on landlords from code enforcement agencies and legislatures. Comment, Rent Withholding, stipra note 7, at 323-4, 327 n.112; Withholding Rent: New Weapon Added to Arsenal for War on Slumlords, 21 J. Housing 67, 70; Note, Rent Strike Legislation-New York's Solution to Landlord-Tenant Conflicts, 40 St. John's L. Rev. 253, 259 (1966); N.Y. ReAl Prop. Actions LAW art. 7-A (1965); N.Y. MULT. DWELL. LAW § 302a (1965).

22 Cal. Civ. Code ANn. $\$ 1942$ (1960); LA. Civ. Code AnN. art. 2700 (West 1952); Mass. Gen. LAws ANN. ch. Ill, §§ 127F, 127H (1966); Mo. ANN. Stat. \$§ 441.570, 441.580 (Supp. 1969); Mont. Rev. Code ANN. § 202 (1947); N.Y. Mult. Dwell. LAw § 302a (1965); N.Y. ReAl Prop. Actions LAW $\S 755$ (1965); N.Y. REAL Prop. Actions LAW art. 7-A (1965); N.D. Cent. Code \& 47-16-13 (1960); Orra. Stat. ANN. tit. 41, § 31 (1954); PA. Stat. ANN. tit. 35, § 1700-1 (1966).

23 ILt. REv. Stat. ch. 23, § 11-23 (1969); N.Y. Soc. Welfare LAw § 148b (1962). In addition, Michigan has a statute which provides: "No general relief authorized under this [public welfare] act shall be used to pay rent for any dwelling that does not meet the standard established under this section [minimum housing standards for the maintenance of health and decency]." MICH. CoMp. LAws ANN. \$ 400.14c (1967).

24 The Cook County Department of Public Aid is a state agency administering the state public assistance program in Cook County. The Housing Bureau of the CCDPA administers all aspects of the housing program of the state assistance program, including rent withholding. 
scribed by the housing code of the City of Chicago. ${ }^{25}$ The Department embarked upon the program because it found itself "most unwillingly the largest subsidizer of slums in ... [the] community through the rental allowances which were made to welfare recipients." ${ }^{28}$ It was estimated that of the five million dollars paid by the Department each month in rent allowances, one million dollars was used to pay rent for grossly substandard housing. ${ }^{2 t}$ Thus, it decided to initiate a program of rent withholding to try to force the owners of slum properties to repair and improve their buildings.

Under this program the Department withheld rent only from those landlords who were before the Chancery Division of the Cook County Court for failure to comply with the housing code. ${ }^{28}$ The Department

25 Most rent allowances are paid directly to recipients in their monthly assistance check, the only exceptions being cases where: (1) the landlord requests direct payment in consideration for not raising rent above the Department's ceiling, (2) the recipient is a compulsive alcoholic or narcotic addict, or (3) the recipient has a history of poor management of assistance grants. In cases where the payments were made directly to recipients, the Department withheld rent by deleting it from the recipient's check and informing him not to pay his rent. In cases where the Department made the rent payment directly to the landlord, the Department withheld by stopping payment to the landlord.

The Department is currently considering changing to a system in which all recipients will receive their monthly rent allowances directly. Interview with Victor Spallone, Housing Bureau Chief, CCDPA, in Chicago, April 3, 1970.

26 Statement, Rent Withholding Program, on file in Housing Bureau, CCDPA, in file entitled "Withheld Rents and Notices of Restoration (1961-62)."

27 Withholding Rent: New Weapon Added to Arsenal for War on Slumlords, supra note 21, at 67 . Today the CCDPA pays some six or seven million dollars in monthly rentals for over 366,000 persons. "This involves millions of dollars being spent for inadequate housing." Speech by Victor Spallone, Housing Bureau Chief, CCDPA, Urban Problems Institute Housing Seminar, Chicago, Feb. 18, 1970 [hereinafter cited as Spallone speech].

28 The Chicago Municipal Code (1969) provides that if the Building Commissioner finds any building to be in a dangerous or unsafe condition, he is to notify the owner to repair the building or demolish it. If the owner fails to repair or demolish within thirty days after the notice is given, the Commissioner may refer the building to the city's Corporation Counsel for suit. The Corporation Counsel is authorized to apply to the Chancery Division of the Cook County Circuit Court for an order authorizing the city to demolish or repair the building. The cost of such demolition or repair is recoverable from the owner and is made a lien on the property. Chicago Munictpal Code $\S 39.12$ (1969).

In practice, at the Chancery Court proceedings, the Corporation Counsel never requests an order authorizing the city to repair the building. Instead, the landlord is given an opportunity to repair, and if he fails to do so, the court may appoint a private receiver under ILz. REv. STAx. ch. 24, \$ 11-31-2 (1969). If the landlord fails to repair and if a private receiver cannot be found or if the building is beyond repair, the court will authorize the city to demolish the building. In 1968 the Cook County Circuit Court, Chancery Division, issued 628 mandatory injunctions against landlords to make the needed repairs, issued 703 vacate orders and appointed 448 private receivers. At the end of 1968, there were 3416 cases pending in Chancery. 1968 Progress Report: Workable Pro- 
restored rents if the case was dismissed from Chancery Court for correction of the violations. Between August, 1961 and June, 1965, rent was withheld from 1348 families, consisting of 5001 persons, living in 160 buildings. ${ }^{29}$ The passage and implementation of the withholding statute resulted in significantly increased enforcement: from July, 1965, when the statute went into effect, to December, 1969, the Department withheld rent from 7102 families, consisting of 30,116 persons, living in 1884 buildings. ${ }^{30}$

\section{The Illinots Public Rent Withholding Statute}

The major problem with the pre-statute withholding program was that landlords could evict for nonpayment of rent those recipients whose rent allowances were withheld. The Illinois legislature remedied

gram for Community Development, City of Chicago Report to United States Department of Housing and Urban Development (June 1969).

In addition, the Building Department refers cases with less serious uncorrected violations to the Corporation Counsel for prosecution in the Municipal Division of the Cook County Circuit Court. In 1968, the Cook County Municipal Court imposed fines totalling $\$ 44,009$ on landlords owning 2040 buildings. $I d$.

Prior to 1970, the time between initial inspection and referral to the Corporation Counsel could take from four to eight months because the procedure used by the Building Department gave landlords many opportunities for delays and continuances. Hearings of the Illinois State Senate Subcomm. on Local Government Services of the Municipal Corporations Comm., Code Enforcement Problems within the City of Chicago, May 23, 1968, 117-21 [hereinafter cited as the 1968 Hearings] (testimony of Anthony Haswell, President of the Park West Community Association). According to one Building Department official, in early 1968 the Department began sending the "most severely damaged properties" to the Corporation Counsel immediately, rather than through the regular Building Department procedure. Id., July 9, 1968, at 12-14 (testimony of Abel D. Swirsky, Chicago Building Department, Deputy Commissioner, Division of Community Conservation and Development).

In early 1970, the Building Department instituted a new policy whereby the Chief of Compliance of the Department decides after the initial inspection whether: (1) the owner will be given thirty days to comply, (2) the building will be referred to the Compliance Board, or (3) it will be referred to Corporation Counsel for court proceedings. The decision will depend on the seriousness of the violations. This new procedure should considerably shorten the time between initial inspection and compliance or demolition. Interview with James Brick, District Director, Compliance Division, City of Chicago Building Department, in Chicago, April 21, 1970.

29 According to the Department's records, the total of rent withheld per month during the four-year period was $\$ 81,433$. The Department obtains this figure by adding all the individual rent allowances for all recipients from whom rent was withheld at any time during the period. Since in most cases, the rent was probably withheld for more than one month, however, the figure should be regarded as an underestimate of the amount actually withheld in the period. On the other hand, since the figure is based on the Department's central files, it may be somewhat inflated, because in nearly $10 \%$ of the sample cases where the Central Administrative Office believed rent was being withheld, there were no recipients in the buildings at the beginning of the withholding period.

80 The total amount of rent withheld per month during the period was $\$ 595,126$. 
this problem in the 1965 statute by establishing a defense against eviction during withholding.

The statute provides that if the public aid department knows that a building occupied by public aid recipients "violates any law or ordinance establishing health and safety standards and by reason thereof is in a condition dangerous, hazardous or detrimental to life or health, it shall report the building to the appropriate municipal or county authority which shall promptly investigate and report its findings" to the Department. If this report establishes violations, the Department shall notify the owner or his agent that unless violations are corrected within ten days, rent allowances or direct payments will be withheld. ${ }^{31}$

As Figure 1 indicates, the administration of the rent withholding statute is extremely complex.

The enforcement process can be divided into two general stagesthe referral stage and the withholding stage.

1. The referral stage. The CCDPA's implementation of the statute begins with the receipt of the initial complaint by the Central Administrative Office of the CCDPA (hereinafter referred to as the GAO). The GAO receives complaints from three sources: its own housing consultants, the City of Chicago Building Department, and community groups. The housing consultants, working out of fifteen district offices, are responsible for inspecting all recipient moves which are planned in advance ${ }^{32}$ and all recipient occupied buildings on which complaints

31 ILI. REv. STAT. ch. 23, \& 11-23 (1969). It appears from the wording of the statute, that, in order for the Department to withhold rent, the violations need not be actually in the dwelling unit occupied by the recipients, but rather may be in any part of the building, even in dwelling units occupied by nonrecipients. In practice such a situation probably occurs infrequently, however, because the condition of most of the withholding buildings is so poor that there will be violations either in the recipient's dwelling unit or in the common areas of the building.

32 Each district office has a housing unit consisting of a housing consultant with from one to three investigators under him. For purposes of simplicity the discussion in the text refers only to the housing consultant rather than to the housing unit or the investigators. Since only half of the 4000 monthly moves by Cook County recipients are planned in advance, it is often impossible for an investigation to be made before the move occurs. Statement by Victor Spallone, before the Advisory Committee to the Cook County Department of Public Aid, in Chicago, Jan. 21, 1970.

If the housing consultant is informed of a move in advance, an inspection of the building will be made before the move, and authorization will be given only if the building meets the housing standards. Spallone speech, supra note 27. Unfortunately, due to the acute low income housing shortage in Chicago, many moves apparently cannot be technically authorized but simply must be acquiesced in by the housing consultant. For example, in December, 1969, of the 2603 inspections conducted for planned recipient moves known in advance by the housing consultants, $65 \%$ of the inspections revealed sound structures, $24 \%$ deteriorated, and $11 \%$ dilapidated. Of this last group, less than $10 \%$ of the recipients involved were placed in different housing. Report of Housing Consultants for the month of December, 1969, Cook County Department of Public Aid [hereinafter cited as Housing Consultants Monthly Report]. 
Figure I

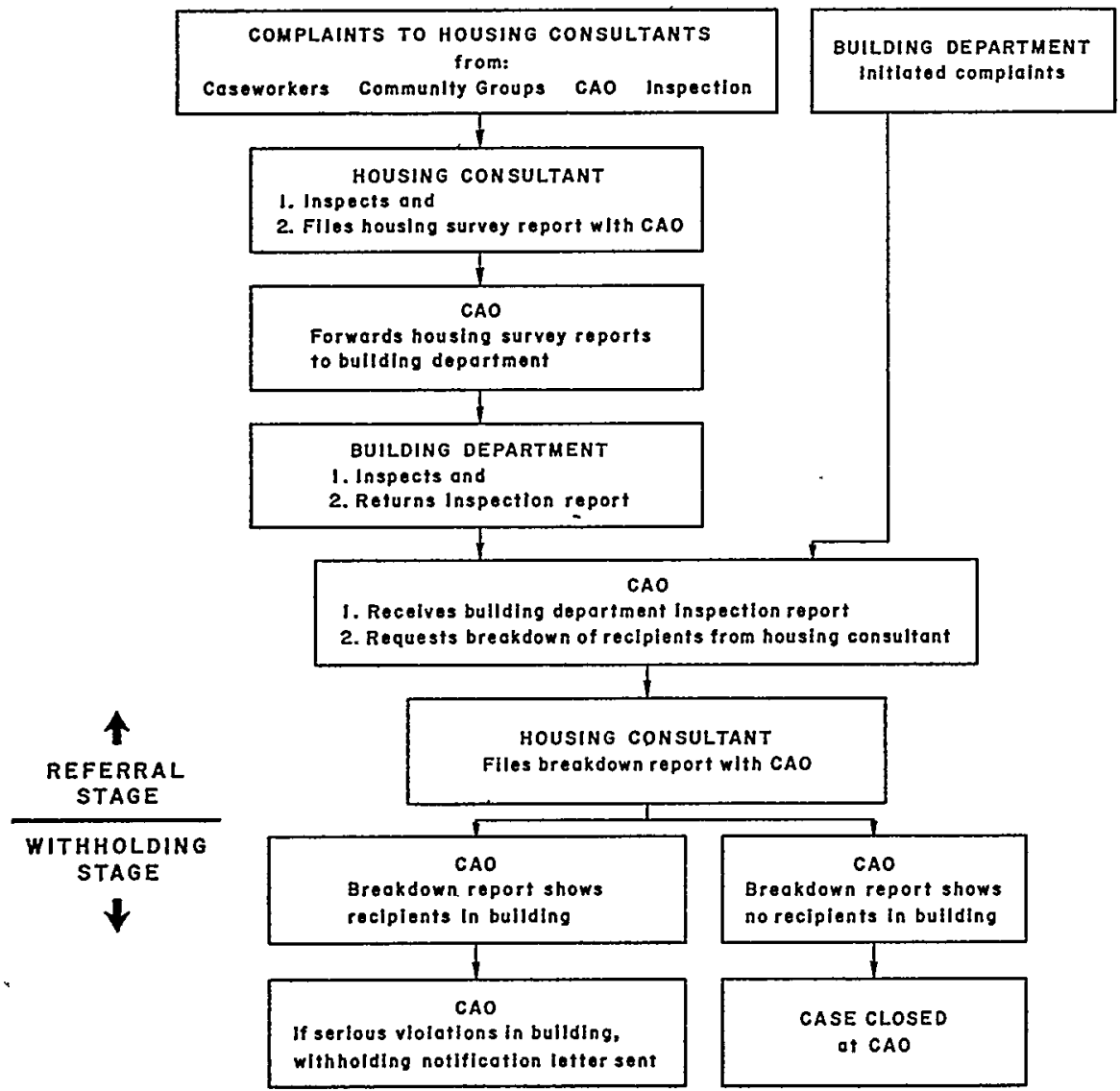

of code violations are received. ${ }^{33}$ The housing consultant files a housing survey report $\mathrm{t}^{34}$ with the $\mathrm{CAO}$ for those buildings in which he finds violations. ${ }^{35}$

33 In December, 1969, the housing consultants or their investigators received 3724 new requests for inspections. Of these, approximately $28 \%$ involved complaints concerning building code violations in recipient occupied buildings, approximately $71 \%$ involved requests for inspection of a nonrecipient occupied building because of a planned move by a recipient, and $1 \%$ involved requests for inspection of nonrecipient occupied buildings for future reference by the housing unit. Housing Consultants Monthly Report, supra note 32. Complaints come primarily from caseworkers, but also from recipients, community groups, and city aldermen. When the $\mathrm{CAO}$ receives complaints from these or other sources, it refers the complaints to the proper housing consultants.

34 The housing survey report is a Chicago Building Department form which contains information about the location, ownership, occupancy, type and condition of the building. Interview with William Taylor, Housing Consultant, Midway District Office, Cook County Department of Public Aid, in Chicago, Feb. 11, 1970 [hereinafter cited as Interview with Housing Consultant].

85 If the housing consultant does not personally inspect, he must verify the housing survey report submitted by his investigators. The report must be forwarded by the housing 
When the CAO receives a housing survey report, or a report of violations from a community group, it forwards the report to the Building Department for verification. ${ }^{36}$ Such verification is unnecessary for complaints initiated by the Building Department, which sends to the CAO all cases which have been referred to the Corporation Counsel for prosecution in the Chancery Court. ${ }^{37}$ Once'verification or the Chancery Court complaint is received, the GAO requests breakdown reports from the district offices. These reports inform the CAO whether there are public aid recipients in the building, and if so, how many. ${ }^{38}$

2. The withholding stage. If there are recipient occupants, a CAO staff member decides whether the violations are serious enough to warrant withholding. ${ }^{39}$ If they are, the landlord's name and address

consultant to the CAO within five working days after the inspection is made. Bulletin 70.24, Procedures for Withholding and Restoration of Rental Payments, CCDPA, May 8, 1970, at 2 [hereinafter cited as Bulletin 70.24]. Of the 3637 inspections of recipient occupied buildings and inspections for planned moves conducted by the fifteen district housing units in December, 1969, approximately 329 housing survey reports, or $8 \%$, were forwarded to the CAO. Housing Consultants Monthly Report, supra note 32.

The housing consultant also contacts the landlord and asks him to make the necessary repairs. If the landlord is uncooperative, or the consultant has reason to believe that he will not act in good faith, the consultant informs him that his rent will be withheld or that there will be court action if he fails to make the repairs. Housing Consultant Taylor said that he threatens the landlord with court action rather than with withholding. Taylor said that he knows that many landlords, if forced into court, will comply. Interview with Housing Consultant, supra note 34. For a discussion of Building Department procedure concerning referral of cases to Corporation Counsel, see note 28 supra.

36 In some cases the Building Department sends a report of a previous inspection and in other cases it conducts a new inspection.

37 The buildings referred to the CAO by the Building Department are sent either in a list of buildings or in that part of the Chancery Court complaint which indicates ther existing code violations. If only a list is sent, then the CAO writes to the Building Department asking for the complaint so that it may obtain an official list of the violations. See note 28 and accompanying text supra.

- 38 The study revealed that the CAO requests a breakdown report for every building on which the Building Department report indicates violations. A CAO staff member then reviews the building file after a breakdown, indicating whether recipients live in the building, is received, and makes a determination as to whether the violations are serious enough to warrant withholding. Interview with Victor Spallone, Morton Miller and Samuel Barenbaum, Housing Bureau, CCDPA, in Chicago, April 13, 1970 [hereinafter referred to as Interview with CAO staff]. See notes 112-5, 130-4 and accompanying text infra for an examination of the data pertaining to the breakdowns.

The breakdown information is usually not filed with the initial housing survey re. port because: (1) there were no recipients in the building when the report was filed or (2) if the building did contain recipients at that time, they will have moved by the time the Building Department report is received. If the breakdown information is filed with the housing survey report, the CAO will not request another breakdown after receipt of the Building Department report unless the breakdown is over six months old. Interview with CAO staff; Interview with Housing Consultant, supra note 34.

30 In making this determination, the $\mathrm{CAO}$ attempts to evaluate each case individually 
are typed on a withholding notification form letter which must be signed by the Director of the CGDPA. ${ }^{40}$ If repairs are not made within ten days after the notification letter is mailed, the CAO sends a withholding memorandum to all district office supervisors and housing consultants, directing them to withhold rents from the building in question. ${ }^{11}$

Under the statute, if the Building Department, or other appropriate agency, determines that the violations have been corrected within ninety days after the notification letter was mailed, all withheld rent is to be paid..$^{42}$ Prior to 1970 , the CAO required housing consultant verification of the Building Department's determination that violations had been corrected before it would restore rents. ${ }^{43}$ After verification, the $\mathrm{CAO}$ sends a memorandum ordering immediate restoration to all district office supervisors and housing consultants. A disbursing order, payable to the landlord,44 is drawn in the amount of rent withheld during the withholding period. ${ }^{45}$

If the repairs are not made within ninety days, due to the "fault or negligence" of the landlord, the statute authorizes the Public Aid

in terms of the people involved, the state of the building and the condition of the neighborhood. Interview with CAO staff, supra note 38.

40 Prior to 1970 , the notification letters were usually not sent immediately after the breakdown was received, but rather in group mailings every few months. See note 165 infra. In serious cases, however, the letter was sent immediately after the breakdown was received. Under the Department's current procedure, all notification letters are sent out as soon as possible after the report is received. Interview with Victor Spallone, supra note 25 .

41 The purpose of sending the withholding memo to all district office supervisors and housing consultants is to aid them in authorizing planned moves outside their districts. Interview with CAO staff, supra note 38 .

12 The statute does not specify to whom the withheld rent is to be paid. Presumably it would be paid to the owner, lessor or management agent to whom the tenants made their rent payments. See note 44 infra for a discussion of the Department's restoration policy when ownership changes after the initiation of withholding.

43 See notes 60 \& $62-70$ and accompanying text infra for a discussion of what constitutes proof of compliance and verification.

44 If the owner at the time of restoration is not the same person as the owner at the time of the initial withholding, the new owner will be paid only the amount of rent which was withheld while he owned the building. Any amounts withheld before he became owner will be paid to the previous owner. In practice, the new owner generally obtains an assignment of the previous owner's rights, allowing the Department to pay all rent directly to the new owner. Interview with Victor Spallone, Housing Bureau Chief, CCDPA, in Chicago, Feb. 13, 1970.

45 The memorandum is sent to all district office supervisors and housing consultants because back rent must be restored for all recipients who lived in the building at any time during the withholding period. While the housing consultant in the district where the building is located has primary responsibility for restoration, he must obtain information concerning recipients who moved from the housing consultant in the district to which they moved. 
Department to deduct 20 per cent of the payments withheld as an "administrative penalty." For each thirty-day period thereafter, during which violations remain uncorrected, 20 per cent of the withheld rent for that period is deducted. If all repairs are made before the expiration of any subsequent thirty-day period, the 20 per cent penalty is prorated over the period that violations still existed. ${ }^{46}$ The Department may, subject to these 20 per cent penalty provisions, make partial payment of the withheld rent if the violations have been partially corrected and there is proof of a good faith effort to correct all violations.

Finally, the statute provides that in any action brought against a recipient for nonpayment of rent withheld under the statute, it is a valid defense to show that existing violations remain "of a character confirmed in a report of a municipal or county authority as dangerous, hazardous or detrimental to life or health." The report is prima facie evidence of the existence of violations. The public aid department is permitted to intervene on behalf of the recipient in any such action for nonpayment "or in any other action for nuisance or otherwise" brought by the landlord or his agent during the withholding period.47

Before examining the problems that arise in the referral and withholding stages of the administrative process, a brief discussion of the research methods used in this study is warranted. The basic source of information was the records of the enforcement agency. The CAO maintains a file for each building on which a complaint has been received. There is also a control card for each building, which theoretically contains all major entries in each building file. ${ }^{48}$ The universe of the sample analyzed consisted of all buildings first entered on the

46 The $20 \%$ penalty provision became effective July 24, 1969. The Department's policy is to apply the penalties only in those cases where withholding began after the effective date of the amendment. It does this even in those cases, subsequent to the amendment, where the pre-amendment form notification letter was used, even though the letter did not contain specific reference to the penalty provisions. The Department's justification for this procedure is that the pre-amendment notification letter did state that withholding would be carried out "pursuant to the statute and amendments." Interview with CAO staff, supra note 38 .

There is no discussion of the penalty provisions in the analysis of the sample because the CAO did not begin implementing the provisions until after the study concluded.

47 In addition, ILI. REv. STAT. ch. 23, § 11-23.1 (1969) provides that should the landlord of any building occupied by recipients from whom rent allowances are being withheld cause the termination of utility services in that building, the Public Aid Department is authorized to pay for those utility services and to be reimbursed from the withheld rent.

48 The control cards were not accurate in all cases. For example, many did not contain all the major entries in the file and a few contained information which was inaccurate. Therefore, it is possible that some 1968 initiated cases were excluded from our universe and, similarly, that some non-1968 cases were included. 
control card $^{49}$ in 1968.50 These cases were listed in the same order in which they were filed by the CAO, i.e., alphabetically by street name and then numerically by street address. Of the 1635 cases initiated in 1968, a systematic sample of every eighth case, or 204 cases, was selected. ${ }^{31}$ For these cases, all information available in the CAO files,

49 The first entry on most of the control cards was either "Check List Sent," the date on which the housing survey report was forwarded to the Building Department, or "Report from Building Department," the date on which the list of buildings referred to Corporation Counsel for prosecution was received at the CAO.

In defining our universe we encountered two problems. First, the "Check List Sent" date accurately indicates when the case came to the attention of the CAO but not when the housing consultant received the complaint which led to his inspection. Since usually only a short period of time elapsed between actual inspection and referral to the Building Department, in determining which cases fell within our universe we checked those cases which had as the first entry on the control card "Check List Sent" in the first 15 days of January, 1968, in order to establish if the initial inspection actually occurred in December, 1967. We followed no comparable procedure for January, 1969, and because of this, we undoubtedly omitted from the universe some cases which were initiated in December, 1968, but which were not referred to the Building Department until January, 1969.

However, to have separated all the 1968 cases from the 1969 initiated cases would have proved virtually impossible because although $80 \%$ of the cases were referred by the CAO to the Building Department within 15 days after they were received from the housing consultant, some cases were retained in the district office for as many as 85 days before being forwarded to the CAO for referral.

Because of these "stragglers," we chose to cut the sample at December 31, 1968. If the housing survey report had not yet been referred to the Building Department at that time, we did not include the building in the universe. The exclusion of these few cases does not appear to have prejudiced the sample since we found very few seasonal variations. We found nothing unique about the cases initiated in January, 1968 or those initiated in the first part of December, 1968 when compared with cases initiated during the remainder of the year.

Second, in determining which cases had actually been initiated in 1968, we faced the problem that many cases were technically already open as of January 1, 1968. Although they had been initiated prior to 1968 , they had stagnated in the administrative processes. To maintain the accuracy of the universe, we treated these cases as having been initiated as of the earliest date, either initial inspection by the district office or the initial referral from the Building Department, and not as being within the 1968 cases. Consequently, even if new housing survey reports or new Building Department reports were filed with the CAO during 1968 on these buildings, these cases were not considered as having been initiated in that year for the purposes of our study. Since the files in no way indicated which subsequent housing survey reports were follow-ups on the part of the housing consultants in the district offices, it was almost impossible to distinguish a follow-up from an entirely new complaint. Those cases which had been officially closed prior to, or during, 1968, and reopened in that year were included in the universe. Further, in the very few instances where the file had been opened, closed and reopened all in the year 1968, we counted them as two separate cases.

60 The calendar year 1968 was chosen for two reasons: (1) in order to allow all sample cases at least one year to reach final disposition, and (2) in order to allow the Public Aid Department three full years in which to resolve any initial administrative problems.

01 The nature of the CAO's filing system, the fact that no two city blocks in Chicago are identical, and the fact that the number of recipient buildings per block varies con- 
as well as selected specific information from the district offices, was obtained. For all withholding cases for which the CAO files indicated that compliance had not been achieved, a questionnaire was sent to the district office to determine whether public aid recipients still resided in the building and whether the building remained substandard. For those cases which never reached withholding, a similar questionnaire was sent to the district offices to determine the present condition of the buildings. This material was supplemented with inspections of Building Department records and interviews with housing consultants, landlords, judges and various members of the staff at the GAO.

The remainder of this paper will consider (A) problem areas in the enforcement process, (B) an evaluation of enforcement, and (C) criteria for effective enforcement.

\section{A. General Problems in the Implementation of the Statute}

While the statute explicitly delineates the procedures to be followed in withholding and restoration, the study revealed a number of problems in the CCDPA's implementation of the statute.

1. The Role of the Recipient. The individual public aid recipient has no control over' the withholding process. Only after the CAO decides to withhold is the recipient informed that his rent allowance will be deleted from his monthly check. Although the CAO staff maintains that most recipients do not object to having their rent withheld, ${ }^{52}$ one housing consultant said that some recipients do object and ask the Department to restore rent, but that the Department refuses. ${ }^{53}$ Further, in some cases of landlord coercion, the recipients continue to pay rent "under the table" even though they no longer receive rent allowances. The Department is rarely able to detect such cases, but they undoubtedly exist. ${ }^{54}$

It is ironic, in light of the lack of control recipients exercise over

tribute to the representativeness of the sample. Thus, throughout the remainder of this study, we shall proceed on the assumption that, except where noted, what is true for the sample is true for all cases initiated in 1968.

52 Interview with $\mathrm{CAO}$ staff, supra note 38.

53 Interview with William Taylor, Housing Consultant, Midway District Office, CCDPA, in Chicago, May 1 and 2, 1969. These interviews were conducted before the Department instituted its present policy of allowing all recipients an informal hearing before any deduction is made from their monthly allotment. See note 56 and accompanying text infra. In later interviews, however, Housing Consultant Taylor indicated that the current policy actually does little to influence the recipient's control over the withholding process. See note 57 and accompanying text infra.

54 Interview with Redmond Peters, Administrative Assistant to Bureau Chief, CCDPA, in Chicago, April 11, 1969. 
the withholding process, that the underlying philosophy of public assistance is that the recipient should be free to control his own fate. ${ }^{55}$ Some aspects of the Department's procedure seem to embody the philosophy of recipient self-reliance, but in practice do little to apply that philosophy to rent withholding. For example, the Department notifies the recipient, ten days prior to the deletion of his rent allotment, of the amount of and reasons for the deduction and of his right to a hearing to contest it. ${ }^{56}$ This notification is an empty formality, however, for the recipient has no control over the initial withholding decision and, in order to change the decision, he must prove at a hearing that there are no violations. ${ }^{57}$

The restoration procedure also gives only lip service to the philosophy of recipient self-reliance. When restoration of rent is ordered, the recipient must sign a disbursing order, previously prepared by the caseworker, assigning his rights to the rent so that the state comptroller can pay it directly to the landlord. The assignment is necessary since the withheld rent theoretically belongs to the recipient and cannot be released without his consent. Moreover, the CCDPA recently instituted a new operating procedure, effective May 8,1970 , which has eliminated the requirement that the recipient sign the disbursing order, thus removing any pretense that the withheld rent belongs to the recipient.

While the statute apparently authorizes the Department to deny

55 The Social Security Act, 42 U.S.C. $\$ 301$ et seq. (1964), provides that state public assistance programs which use federal funds should make "money payments" to recipients. The Social Security Administration has transformed this into the "money payments" principle.

The provision that assistance shall be in the form of money payments is one of several provisions in the act designed to carry out the basic principle that assistance comes to the needy persons as a right. ... The Social Security Administration's interpretation of "money payments" recognizes that a recipient of assistance, does not, because he is in need, lose his capacity to select how, when and whether each of his needs is to be met.

Social Security Administration, Department of Health, Education and Welfare, Handbook of Public Assistance Administration, Part IV, § 5120, Sept. 26, 1947.

56 This standard form letter is sent to recipients whenever the Department intends to decrease or terminate their monthly allotment. In some cases, the recipient is informed of the Department's intended decision by the caseworker in person rather than by mail. Such notification is intended to provide the recipient with an opportunity for a hearing prior to the reduction or termination. The Department began this notification procedure following Golliday v. Robinson, 305 F. Supp. 1224 (N.D. Ill. 1969), in which the court held that the due process clause of the fourteenth amendment requires the welfare department to give a recipient notice and an opportunity for a hearing prior to any reduction or termination of his monthly allotment. See also Goldberg v. Kelly, 90 S. Ct. 1011 (1970), where the United States Supreme Court came to a similar conclusion.

57 Housing Consultant Taylor said that if the recipient wishes to contest the decision to delete his rent allotment, he must in effect prove the landlord's case. This will be virtually impossible in most instances, because the landlord will not have corrected the code violations. Telephone conversation with William Taylor, Housing Consultant, Midway District Office, CCDPA, in Chicago, Feb. 19, 1970. 
recipient control over withholding, this denial seems unjustified. The underlying principle of public assistance, as discussed above, is that the recipient should be free to control his own fate; the Department's procedures directly conflict with this philosophy. Moreover, the basic argument urged in support of the Department's position, that recipient control would seriously dilute the effectiveness of rent withholding, seems doubtful in light of the effectiveness of recipient control experienced in those states having private rent withholding programs. ${ }^{68}$

2. Notification of Withholding. The statute requires the Department to notify the landlord, by registered or certified mail, of its decision to withhold at least ten days before the decision goes into effect. ${ }^{69}$ Figure 2 indicates that in the sample group the Department mailed fifty-seven initial withholding notification letters. Thirteen of these letters were returned to the Department marked "unclaimed," "addressee unknown," or "moved, no forwarding address." The Department attempted to obtain new information from the housing consultants concerning the addressee in all thirteen cases. In eight of these cases the Department received new information and sent a second letter. ${ }^{00}$ In the five cases for which no new information was received, the Department withheld in one without sending a second letter and dropped the other four from the enforcement process.

These last five cases present a problem frequently confronted by the Department: what to do when the landlord refuses to accept the letter. The Department's stated policy in such cases, in conformity with the statute, is not to withhold unless it is clear that the landlord refused to accept, and that the refusal was due to his knowledge of the nature of the letter. ${ }^{61}$ In the one case in which the Department withheld without sending a second letter it apparently believed that the landlord had knowingly refused the first letter.

The Department undoubtedly faces a difficult task in determining whether the landlord refused to accept because he knew the letter was a rent withholding notice. If the letter is returned marked "refused,"

58 The growing awareness by tenants and public aid recipients of the power they can exercise through organizations such as tenant unions and welfare rights organizations would tend to discredit the Department's position. Further, only Illinois and New York have public rent withholding statutes while other states have adopted private withholding statutes which are by definition dependent upon tenant control. See notes 22-23 supra and accompanying text.

50 ILL. REv. STAT. ch. 23, § 11-23 (1969).

60 In seven of the eight cases where a second letter was sent, the landlord accepted the letter; in six of these cases, the Department subsequently withheld rent, and in the seventh the landlord complied before withholding. In the one case where the letter was not accepted after the second mailing, all the public aid recipients had moved before the Department obtained new information concerning the landlord.

61 Interview with CAO staff, supra note 38. 


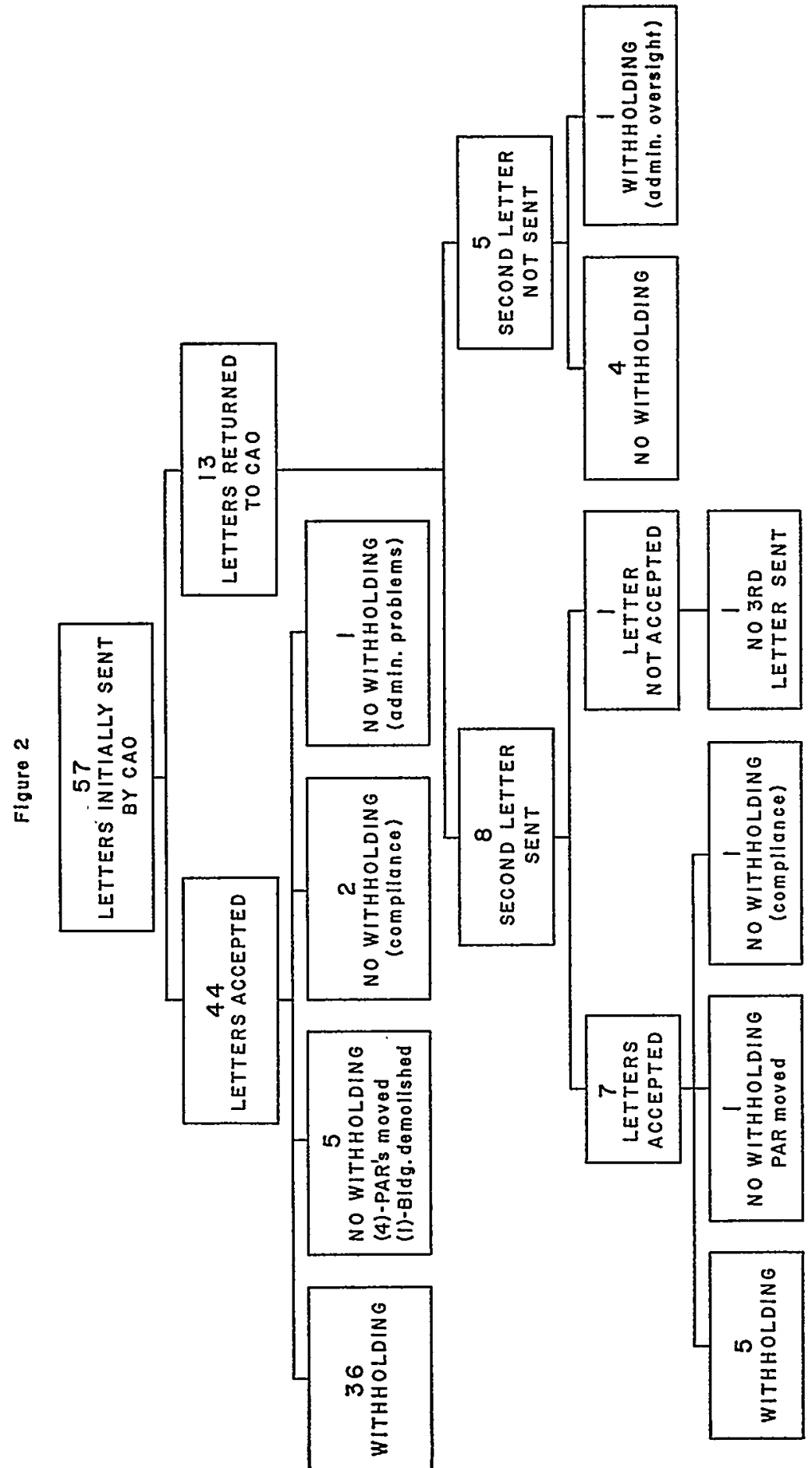


it could be persuasively argued that the landlord had received constructive notice; none of the returned letters were marked "refused," however. It is likely that some of the "unclaimed" letters were, in reality, refused. In some cases the landlord, while unavailable when delivery was first attempted, may have failed to claim the letter because he knew it was a withholding notification. In other cases the landlord may have simply denied his own existence and told the postman that no such person lived at that address. While the Department apparently decides on a case by case basis whether the landlord knowingly refused the letter, the standards used in making this determination, if any, are unknown.

Permitting landlords to circumvent the withholding process by simply failing to claim the notification letter is clearly contrary to both logic and legislative intent. Yet this occurred in four of the fifty-seven cases for which letters were initially sent. This could have been prevented by either sending the second notification in a plain envelope, as was done in one case, or by attempting to personally contact the landlords. While the latter may not meet the strict statutory requirements of notice, it can be justified as within the purposes of the statute. To meet these notification problems, the statute might be amended to allow notice by means other than registered or certified mail.

Finally, if one of the reasons for the ten-day notification letter is to provide the landlord with an opportunity to repair or begin repair before withholding, the letter seems to be of little value. Since, in most cases, ten days simply is insufficient to repair serious violations, it may be that the legislature expected ten days to be adequate for the landlord at least to begin repairs.

In only ten of the fifty-one cases in which withholding letters were sent and accepted did the landlord allege that repairs had been completed or were in progress during the ten-day period. In six of these cases the Department did not withhold at the end of the ten-day period pending reinspection, but in only one of these six were the repairs actually completed within the ten days. Thus, the ten-day grace period seems to be little more than a formality.

3. The Role of the Building Department in the Withholding Process. The statute requires that an appropriate municipal or county authority determine whether the landlord has complied and whether withheld rent should be paid. ${ }^{2}$ The appropriate authority in Cook County is the Building Department. In March, 1970, the CCDPA made significant changes in its procedure concerning this requirement. ${ }^{63}$ The following

62 ILL. REv. STAT. ch. 23, § 11-23 (1969).

63 On March 18, 1970, the Housing Bureau Chief, Victor Spallone, and the City of Chicago Building Commissioner, Joseph Fitzgerald, formulated a new procedure con- 
discussion focuses primarily on the previous procedure, however, because it was applied during the sample year and is helpful in explaining some of the data.

Under the old procedure, the Department would not restore rents unless the landlord obtained a certificate of inspection from the Building Department indicating that no violations existed..$^{64}$ It was almost impossible for a landlord to obtain such a certificate if the Building Department inspector knew that there were public aid recipients in the building or that the Public Aid Department was withholding rent. ${ }^{65}$ Moreover, the Department would not order restoration unless there had been a housing consultant determination that no violations existed. This procedure was followed even where the landlord had obtained a Building Department certificate indicating no violations or a dismissal from Chancery Court based on a Building Department inspector's testimony. ${ }^{\circ 6}$ Continued withholding in these cases would seem to contravene the statute, which authorizes the Building Department to make the determination as to compliance.

This divergence from the statute was generally inconsequential, however, since the housing consultant inspections usually confirmed the Building Department certificates. But the divergence was important in the few cases where the housing consultant reported violations after

cerning determination of code compliance pursuant to restoration. The sample cases pre-date the new policy. See notes $64 \& 70$ and accompanying text infra.

64 In some instances the housing consultant, on his own initiative, may recommend restoration before the landlord has obtained a certificate of inspection. In such cases, the CAO will first check the building file for the last Building Department inspection. If it appears that the building could have been repaired between the last Building Department inspection and the housing consultant's inspection, the CAO will then ask the Corporation Counsel if there is a Chancery case pending on the building. If there is none, the CAO will order restoration. Interview with CAO staff, supra note 38.

65 But Housing Consultant Taylor said that if the landlord could obtain such a certificate and the housing consultant found the building to be substandard, he would recommend restoration. Interview with Housing Consultant, supra note 34 . The reluctance to issue such certificates was largely a result of the 1968 Hearings, supra note 28.

60 It is not entirely clear how this policy would have affected situations in which the landlord obtained a Chancery Court dismissal while the housing consultant reported that violations still existed. Even though the Chancery proceeding is, in effect, a court adjudication on the question of compliance, the Department still required a housing consultant inspection and recommendation before it would restore.

In practice this requirement may have been little more than a formality, because as Housing Consultant Taylor indicated, if the landlord presented a Chancery Court dismissal, he felt somewhat compelled to recommend restoration because he feared that he might be cited for contempt if he did not.

His fear of being held in contempt notwithstanding, Taylor still reinspected before recommending restoration, even if the landlord had presented a Chancery Court dismissal. He said, however, that since the 1968 Hearings, he found all the buildings for which landlords had obtained a Chancery Court dismissal to be in compliance. On the other hand, he did say that in one such building he considered the porch to be structurally 
the building inspector said none existed. ${ }^{67}$ The CCDPA's policy in such cases was to accept the housing consultant's inspections and recommendations concerning restoration. The CCDPA reasoned that the landlord could obtain a court hearing to challenge its decision; if the court ordered restoration, the Department would comply. ${ }^{88}$ In a few cases the courts did order restoration even though the Department considered the building dangerous to the health and safety of its occupants. ${ }^{69}$

The CCDPA's new procedure conforms more closely to the statutory language. The Department still requires the landlord to obtain a certificate of inspection before restoration, but the Building Department will now issue such certificates, indicating existing violations, upon request by the landlord. ${ }^{70}$ If the certificate reports no violations, the CAO will order immediate restoration. If the certificate indicates violations, the CAO will determine whether they are serious enough to warrant continued withholding.

Under the new procedure the housing consultant will not reinspect

defective, but that he was willing to defer to the "expertise" of the building inspector and recommended restoration of withheld rent. Later, when the porch collapsed, Taylor filed a new housing survey report to again begin the withholding process. Interview with Housing Consultant, supra note 34 .

What the other housing consultants would have done if the building still had serious violations after dismissal is unclear. To order restoration and then file a new housing survey report in order to again begin the withholding process, however, would not seem to have been the proper response because not only would it have given the landlord his back rents, but also his current rents until withholding could again be instituted. The Housing Bureau Chief stated that "our experience demonstrates a preponderance of erroneous Chancery Court dismissals." Interview with CAO staff, supra note 38. The sample cases, however, indicated that erroneous dismissals were rare.

67 While the sample group indicated that such disparity was infrequent, the Housing Bureau Chief maintains that it occurred in a majority of cases. Interview with CAO staff, supra note 38.

Among other things, it was discovered at the 1968 Hearings that Building Department inspectors had in a number of cases issued certificates of inspection to slum landlords and testified in Chancery Court that no violations existed in buildings on which the Department was withholding rent, while housing consultants reported that these buildings still had major code violations. 1968 Hearings, supra note 28 . While six Building Department inspectors were indicted for these activities in July, 1969, no convictions have, as yet, resulted. Interview wiith Victor Spallone, supra note 44. See Chicago SunTimes, Feb. 20, 1970, at 4.

68 Interview with CAO staff, supra note 38.

$69 \mathrm{Id}$.

70 At the meeting, the Building Commissioner explained that the reason that some certificates indicating no violations had been issued in the past when some violations did in fact exist is that such certificates were routinely issued for the sale of real property. On such certificates, his department listed only those violations which it considered serious and which would not be obvious to a potential buyer. Now the Building Department will list all violations when a landlord requests a certificate of inspection for a building on which rent is being withheld. Interview with CAO staff, supra note 38 . 
the building to verify the inspection certificate. If after restoration the housing consultant informs the CAO that serious violations still exist, however, the CAO will request the Building Commissioner to order a new inspection. Thus, the emphasis of the new procedure is on working with, rather than around, the Building Department.

4. Delay in Restoration. The statute provides that rent payments are to be restored when all violations are corrected. ${ }^{71}$ In some cases, however, restoration is not effected until long after compliance. Landlords complained of excessive delays in two of the fifteen sample cases which reached compliance. ${ }^{72}$

In the five compliance cases for which figures were available, the housing consultants inspected an average of 21 days after the landlord presented a certificate of inspection or a Chancery Court dismissal to the CAO. In two of these cases the consultant failed to inspect until more than 34 days had passed. ${ }^{73}$ The reasons for these delays are unclear.

The CAO's preparation of the restoration memorandum does not seem to be a significant source of delay. The average time between the housing consultant's restoration recommendation and the CAO's preparation of the memorandum was seven days. ${ }^{74}$ But in over 58 per cent of the cases the time was three days or less, and in only 17 per cent did it exceed two weeks.

Although no figures are available, the disbursing order procedure is probably the most important source of delay. The caseworker is responsible for preparing a disbursing order for each recipient in the building. The housing consultant must then verify the order and, after

71 ILL. REv. Stat. ch. 23, \& 11-23 (1969). This is of course subject to the $20 \%$ penalty provisions and to the partial repair/partial restoration provision. For a discussion of the latter, see notes 79-83 and accompanying text infra.

72 In one case, 114 days after the CAO ordered restoration the landlord complained that he had not as yet received the disbursing order; in the other case the landlord complained after 28 days. A more relevant figure would be the time from when the housing consultant recommended that the CAO restore the rent to when the landlord last complained that he had not received the disbursing order. However, this figure was only available in the second case, namely 32 days.

73 Only five of the fourteen compliance cases had the relevant dates available. The figures for each of the five, in days, are: $1,6,22,35,43$. Unfortunately, dates were not available in the two compliance cases where the landlords complained of delays in receiving their disbursing orders.

It should be noted that in many cases the landlord falsely alleges compliance. Therefore, some delay in reinspecting by the housing consultant may be justified if the landlord is known by the housing consultant to be a disreputable slum landlord. However, if the landlord presents a certificate of inspection from the Building Department or a Chancery Court dismissal it would seem that the housing consultant should reinspect almost immediately.

74 Dates were available in twelve of the fourteen compliance cases. The lengths of time, in days, were: three days or less (seven cases), 6, 13, 14, and 19 (two cases). 
verification, the caseworker must have both the recipient and the landlord sign the order. Apparently the time required for obtaining the signatures depends upon the workload and diligence of the individual caseworker. In many instances the caseworker apparently mails the disbursing order to the recipient, requesting him to sign it, obtain the landlord's signature, and return it to the caseworker. ${ }^{75}$ The potential delays in such a procedure are obvious.

The CCDPA has recently changed this procedure. Under the new procedure, the housing consultant sends an invoice voucher directly to the landlord, who simply signs and returns it. The recipient's signature is not required. ${ }^{78}$ While this procedure should speed up the restoration process considerably, it removes whatever pretense might previously have existed that the withheld rent belongs to the recipient. ${ }^{7 \tau}$

A third source of delay in restoration arises when the recipient moves from one district to another. The disbursing order must be prepared by the recipient's present caseworker and verified by his present housing consultant. Close cooperation is obviously required between the present and former housing consultants if delay is to be held to a minimum. Further, a long delay may occur if the recipient goes off public assistance. Presumably, the former recipient's last caseworker would prepare the disbursing order. If the former recipient has moved from that caseworker's district, the caseworker must mail the disbursing order to the recipient and request a return. The new procedure eliminates most of this delay, however, for the recipient is not required to sign the voucher. ${ }^{78}$

5. Partial Repair/Partial Restoration Provision. The statute provides that upon "proof of good faith effort to correct all the violations" and "upon partial correction of violations" the Department may restore a portion of the rents withheld. ${ }^{79}$ Partial restoration is apparently intended as a reward to encourage the landlord to complete repairs and to provide him with funds with which to do so. However, in only one of the fifteen cases in which compliance was achieved did the Department use the partial repair/partial restoration provision.

One housing consultant said that he never used the provision because most landlords could not he trusted to apply the partially restored rents toward completion of the repairs and that in most cases the withheld

75 Interview with Morton Miller, Administrative Assistant to the Housing Bureau Chief, CCDPA, in Chicago, Dec. 19, 1969.

76 Bulletin 70.24 at 8 , supra note 35 .

77 See note 58 and accompanying text supra.

78 Bulletin 70.24 at 8 , supra note 35 .

79 ILL. REv. STAT. ch. 23, \& 11-23 (1969). 
rents are insufficient to cover the cost of repairs. ${ }^{80}$ Another reason for the apparent unpopularity of this provision may be that the "reward" aspect is ineffective, since the restoration process often requires a great deal of time. ${ }^{81}$

In place of the partial repair/partial restoration procedure, many housing consultants follow what may be termed a "partial repair/full restoration" procedure. In eight of the fifteen compliance cases, housing consultants recommended, and the CAO ordered, complete restoration on the basis of partial repair and good faith intention to complete the repairs. In most of these eight cases, the repairs were 85 to 90 per cent completed when full restoration was recommended. It is questionable whether the statute permits this procedure, but, in light of the long delays often encountered in restoration, ${ }^{82}$ it may be the best way to reward a good faith landlord..$^{83}$

6. The Risk of Eviction. The statute states that a recipient has a valid defense against eviction during withholding if he shows that "existing violations of law remain in the building during the period of residence therein by a recipient of a character confirmed in a report of a municipal or county authority [i.e., the Building Department] as dangerous, hazardous or detrimental to life or health." 84 The statute

80 Interview with Housing Consultant, supra note 34.

81 See notes 71-78 and accompanying text supra.

$82 I d$.

83 It is questionable whether the statute permits the partial repair/full restoration procedure. The statute provides that "if all violations are corrected within ninety days .. . the total rent withheld shall be paid." ILL. REv. STAT. ch. 23, \& 11-23 (1969). Further, the legislature specifically provided for the partial repair/partial restoration situation, and it would appear that where partial repair has been completed, the Department would be authorized to restore rents only partially. However, if one interprets "violations" to mean only those violations which cause the building to be "in a condition dangerous, hazardous or detrimental to life or health," then upon completion of $75 \%$ of all repairs, the landlord may in fact have corrected all the dangerous and hazardous violations.

84 ILL. REv. STAT. ch. 28, \& 11-23 (1969). The statutory defense, however, seems to apply only "in any action of ejectment, distress for rent, or any other action ... based on nonpayment of rent withheld." This discrepancy seems to raise obvious questions of whether the defense applies to an eviction action for "nuisance or otherwise" brought during the withholding period. The Chief of the Bureau of Housing stated that the courts seem to have no problem with the apparent inconsistency and have allowed rent withholding by the Department as a valid defense in any eviction action during the period of withholding, regardless of what the landlord alleges as the reason for the eviction. He also pointed out that the early versions of the statute did not contain the nuisance wording and that some landlords were allowed to evict tenants for nuisance, even though the real reason for the eviction was that the Department was withholding rent. Therefore, the Department recommended that the statute be amended to allow rent withholding as a valid defense against eviction for nuisance. Interview with Victor Spallone, supra note 44.

It should be noted that the statute does provide, seemingly unequivocally, that "[n]o recipient shall be subject to eviction as a result of withholding of rent under this section." This seems to indicate that the statutory defense applies to any eviction attempted during 
further declares that the Building Department report shall constitute "prima facie evidence of a violation or violations." 85 The statute does not declare, however, that the report shall constitute prima facie evidence that the violations are "dangerous, hazardous or detrimental to life or health." Thus, it appears that the final determinations as to the seriousness of the violations, the validity of the withholding, and the applicability of the defense against eviction are left exclusively to the court.

As a result, the court may order eviction simply because the Department improperly withheld rent. While this seems particularly unfair to the recipient, who has no control over the Department's initial decision to withhold, ${ }^{86}$ the study revealed that not only was the risk of court-ordered eviction extremely low, but also that the risk of attempted eviction was low. In only five of the forty-four withholding cases did landlords attempt eviction, and of the thirteen recipients involved in these five cases, only one was evicted. Moreover, this eviction did not involve a judicial determination that the violations were not serious enough to warrant withholding. ${ }^{87}$

The low rate of eviction attempts may be due in part to a landlord belief that the courts will apply the statutory provisions concerning eviction liberally in favor of recipients. ${ }^{88}$ On the other hand, landlords desiring to avoid the eviction process may attempt to force recipients to move ${ }^{89}$ through less formal means, such as threatening not to renew

the withholding period or after restoration in retaliation for the withholding. This provision seems to be qualified, however, later in the statute by the provision cited in the text, so that the defense apparently applies only to those actions brought during withholding.

85 ILL. REV. StAT. ch. 23, § 11.23 (1969).

86 See notes $56-57$ and accompanying text supra.

87 The eviction ordered involved one building where the landlord attempted to evict five public aid recipients. Apparently, the Department received notice concerning only four of the five actions. In the fifth, the one tenant against whom eviction was ordered, notice of the proceedings came to the attention of the Department three months after the eviction took place, when the landlord sent a notice for back rent. At that time, because the recipient was already settled in another dwelling, the Department did not file a motion to vacate the judgment. Apparently the courts have allowed the Department to intervene and have granted motions to vacate eviction orders in similar cases. Interview with Victor Spallone, supra note 44. Presumably, at least one circuit court judge would have discovered at the time of eviction proceeding that the individual was receiving public assistance and would have ordered the clerk to call the CCDPA to ask that a representative be sent. See note 99 and accompanying text infra.

88 One CAO staff member suggested that another reason is that lawyers attempt to discourage landlord clients from bringing eviction actions because the fee involved is quite small in relation to the large amount of time spent in court. Statement of Mr. Morton Miller, Administrative Assistant to Housing Bureau Chief, CCDPA, in Chicago, May 29, 1970.

89 Of course, if the recipient is forced out of the building, either by eviction or landlord harassment, and the landlord does not repair the building, he will not get the back rent. 
the lease or threatening to discontinue utility services. ${ }^{.0}$ The study suggests that either these threats were not made or that they were not successful, for nearly 98 per cent of the withholding buildings still had recipient occupants three and one-half months after withholding began.91 This data is by no means conclusive, however, for it indicates only that at least one recipient is presently in the building, it does not account for the possibility that others might have moved in or out during the period.

The very low risk of court-ordered eviction indicates that the potential problem of courts applying different standards than the Department in evaluating the seriousness of violations is not a significant one in Cook County. The explanation may be either that the courts always agree with the Department's determinations or that the Department withholds only on buildings with clearly dangerous violations. The study suggests that the latter is probably more correct, since none of the withholding cases involved simply minor violations, such as a single broken window or dirty floors. ${ }^{22}$

Problems may arise if the eviction proceeding is initiated after compliance but before restoration,,$^{93}$ since the statutory defense applies only as long as the violations remain uncorrected.94 While technically it would seem that the defense is not applicable, one circuit court judge, rather than ordering eviction in such cases, issues continuances to enable the Department to restore rent. ${ }^{95}$

Another potential problem is retaliatory eviction after restoration. Since most public aid recipients have only thirty-day leases, terminable by either party upon adequate notice and without cause,, 98 landlords

80 Landlords may also use the same threats to attempt to get the recipients to make rent payments even though the Department is withholding their rent allowance.

01 However, only $79 \%$ of the withholding buildings still had recipients in them 313 days after the initiation of withholding. The number of days after withholding that recipients moved out are: 35, 105, 109 (two cases), 140, 246, 304, 308, 313.

92 One judge indicated that if the violations were mere dirt or litter, he would evict. Interview with Judge Joseph Hermes, Associate Judge, Cook County Municipal Court, May 6, 1969. However, since these types of violations appear always to be accompanied by other more serious violations, the risk of eviction seems to be very small.

The judge also indicated that if the landlord proved that the recipient caused the violations, he would evict, although such a case has never come before him. This is interesting because the statute makes no specific provision for landlord defenses and most landlords argue that the violations are mere "housekeeping" items which are not dangerous, and furthermore that the recipient caused them. Id.

93 In practice, this delay period can be quite long. See notes 71-78 and accompanying text supra.

O4 See note 84 and accompanying text supra.

o5 This was the procedure followed by Judge Edith Sampson in one of the sample cases.

96 Wald, Report to the National Conference on Law and Poverty, Washington, D.C., June 23-25, 1965, at 13. The Housing Bureau Chief explained that one reason that recip- 
may choose to evict recipients whose rent was withheld. The Department recognizes this as a possible consequence of withholding, but considers itself unable to do anything more than relocate the evicted recipient. ${ }^{97}$

The Department may intervene on behalf of the recipient in any action "based on non-payment of rent withheld" or "in any other action for nuisance or otherwise brought by the landlord or his agent while the rent is being withheld." 98 While this provision is of little help in cases of retaliatory eviction, it is important when eviction is attempted during withholding. One problem that arises in the implementation of this provision concerns lack of notice to the Department that eviction proceedings have been initiated. The recipient is instructed to notify the caseworker immediately if eviction is attempted. At least one Cook County judge apparently asks every tenant who does not have counsel in an eviction proceeding if he is a public aid recipient. If so, the judge contacts the GCDPA so that a representative can be sent.99

These proceedings are usually attended by a lawyer from the States Attorney's Office, which is technically the Department's legal representative, and either a housing consultant or a CAO staff member. The Department's representative is present not to serve as counsel, but to assist with building records and requests for new inspections.

7. Case Mortality. This section examines the elimination of cases from the enforcement process in the referral and withholding stages of administration.

(a) Case mortality in the referral stage. The referral stage, outlined in Figure 1, may be divided into four steps: initiation, inspection, request and breakdown. ${ }^{100}$ In the initiation step, the CAO receives com-

ients find it difficult to get a year lease is because the Department is not permitted to make a security deposit with the landlord. Interview with Victor Spallone, supra note 44.

97 Apparentiy ILL. REv. STAT. ch. 80, § 71 (1969) is supposed to protect the tenant from retaliatory eviction. It provides:

It is declared to be against the public policy of the State for a landlord to terminate or refuse to renew a lease or tenancy of property used as a residence on the ground that the tenant has complained to any governmental authority of a bona fide violation of any applicable building code, health ordinance, or similar regulation. Any provision in any lease, or any agreement or understanding purporting to permit the landlord to terminate or refuse to renew a lease or tenancy for such reason is void.

However, the statute does not give the Public Aid Department standing to intervene in behalf of the recipient-tenant but rather it gives the tenant individually an affirmative defense. And since the burden is on the tenant to prove that the eviction was retaliatory, this statute appears to offer little aid to a recipient who is the victim of such an eviction.

98 ILL. REv. STAT. ch. 23, \& 11-23 (1969).

99 Interview with Victor Spallone, supra note 44.

100 The four steps in the referral stage are:

(1) Initiation Step: For cases initiated by housing consultants and community groups-

Initial inspection by housing consultant or his investigator- 
plaints from housing consultants, community groups and the Building Department. The CCDPA is itself the most important source of complaints; ${ }^{101}$ housing consultants initiated 73 per cent of the total cases. ${ }^{102}$ The Building Department, through its practice of forwarding Chancery Court complaints to the $\mathrm{CAO},{ }^{103}$ referred 27 per cent of the total complaints, while community groups accounted for less than one per cent.104

The CAO forwards all housing survey reports, received from housing consultants, and all letters of complaint, from community groups, ${ }^{105}$ to the Building Department for verification. ${ }^{108}$ This is done automatically by a clerk, without an evaluation of the violations. Since the CAO need not request inspection reports for those cases initiated by

Processed at District Office-Forwarded to CAO-Processed (file opened) and referred to Building Department for inspection

(2) Inspection Step: Building Department receives referral from CAO-Building inspected by Building Department inspector-Inspection report returned to CAO

(3) Request Step: Receipt of Building Department inspection report

Receipt of Building Department initiated cases (Chancery Court complaints)

Recipient breakdown lists prepared-Breakdown request sent to District Office

(4) Breakdown Report Step: Receipt of breakdown requests in District OfficesHousing consultant obtains list of recipients in building either by asking caseworker or by inspecting the building-breakdown report filed with CAO

101 The source of the complaint is the origin from which the CAO first learns of a substandard building, i.e., the Building Department, housing consultants or community groups. If the housing consultant is the origin, the ultimate source is unknown since he might have received a complaint from a community group, caseworker or recipient. However, the housing consultants receive most referrals from caseworkers. See note 33 and accompanying text supra.

102 See notes $34-35$ and accompanying text supra.

103 See note 37 and accompanying text supra. It would appear that the Building Department referrals are a valuable aid to the CCDPA. Almost $30 \%$ of the buildings referred to the CAO by the Building Department had public aid recipients living in them and the housing consultants had not forwarded the addresses of these buildings to the CAO prior to the time the CAO received the Building Department's referral.

104 See note 33 supra. This would seem to support the statement of one housing consultant that the Department receives very little help from community groups. However, the one community group complaint in the sample is not totally representative of community group participation. If the group contacted the housing consultant without at the same time notifying the $\mathrm{CAO}$, the resulting housing survey report would have been recorded as a housing consultant initiated case in our sample. Therefore, the community group role, either directly by filing complaints or indirectly by making recipients more aware of their rights, might be much greater than the data indicates.

105 Although the housing survey report lists the violations, the letter from the community group merely stated that building code violations existed on the premises and that public aid recipients lived there.

100 The statute requires that the withholding be based on a report of the intermediate department or agency responsible for making such determinations. IrL. REv. STAT. ch. 23, $\S 11-23$ (1969). See notes 31 \& 33 and accompanying text supra. 
the Building Department, ${ }^{107}$ it had to request such reports in only 73 per cent of the total cases. The GAO made requests in all cases requiring inspection reports.

The inspection step includes the Building Department inspection and the return of the inspection report to the CAO. The Building Department initially returned reports in 60 per cent of the total cases, or in 82 per cent of the cases for which reports were requested. ${ }^{108}$ This is a critical stage in the procedure, for if no inspection report is received the withholding process ends unless the $\mathrm{CAO}$ or the housing consultants follow up on the initial request. The Building Department's failure to return reports upon initial request temporarily eliminated 13 per cent of all cases from the enforcement process.

The follow-up procedure, however, recaptured some of this loss. The CCDPA made a second request in one-third of the cases for which no Building Department report was initially returned, and the Building Department returned reports in 62 per cent of these cases. ${ }^{109}$ Thus, the follow-up procedure recaptured 3 per cent of the original cases. The failure of the Building Department to return inspection reports, coupled with the failure of the CCDPA to follow up, eliminated over 10 per cent of all cases from the enforcement process.

The request step begins when the $\mathrm{CAO}$ receives either a Building Department report for those cases initiated by housing consultants or

107 For cases initiated by the housing consultants and community groups, a Building Department inspection must be obtained. ILL. REv. STAT. ch. 23, § 11-23 (1969). See notes 31 \& 33 and accompanying text supra.

108 There was not a single case in the sample in which the Building Department returned a report with no violations in response to the initial request for an inspection. The fact that a report is not returned on a building is not the equivalent of a no-violation report. It simply means that no inspection was ever conducted for that building or that no report of an inspection was forwarded to the CAO.

At the 1968 Hearings the Building Department apparently maintained that it did not realize that the CCDPA wanted it to return reports on all the housing survey reports which the CCDPA forwarded to it. Interview with CAO staff, supra note 38 .

108 The CAO was responsible for $63 \%$ of the follow-ups which were eventually made by the CCDPA while the housing consultants accounted for the remainder. At least one housing consultant attempts to reinspect all buildings within his district once every six months, and such reinspections provide an excellent method by which housing consultants could follow up on buildings which have been reported to the $\mathrm{CAO}$, but on which no action has been taken. Interview with Housing Consultant, supra note 34.

Staff members at the CAO stated that the reason no follow-ups were made in a consistent manner was that the Building Department ignored the Department's follow-ups. Interview with CAO staff, supra note 38. The data does not support such an assertion. In fact, the Building Department returned inspection reports in $62 \%$ of cases referred to it on a follow-up.

In April, 1970, however, the CAO began a systematic follow-up procedure for all cases referred to the Building Department since January, 1970 and on which the Building Department had not filed an inspection report. Interview with the CAO staff; Interview with Mrs. Janet Kendrick, Secretary, Bureau of Housing, CCDPA, April 16, 1970. 


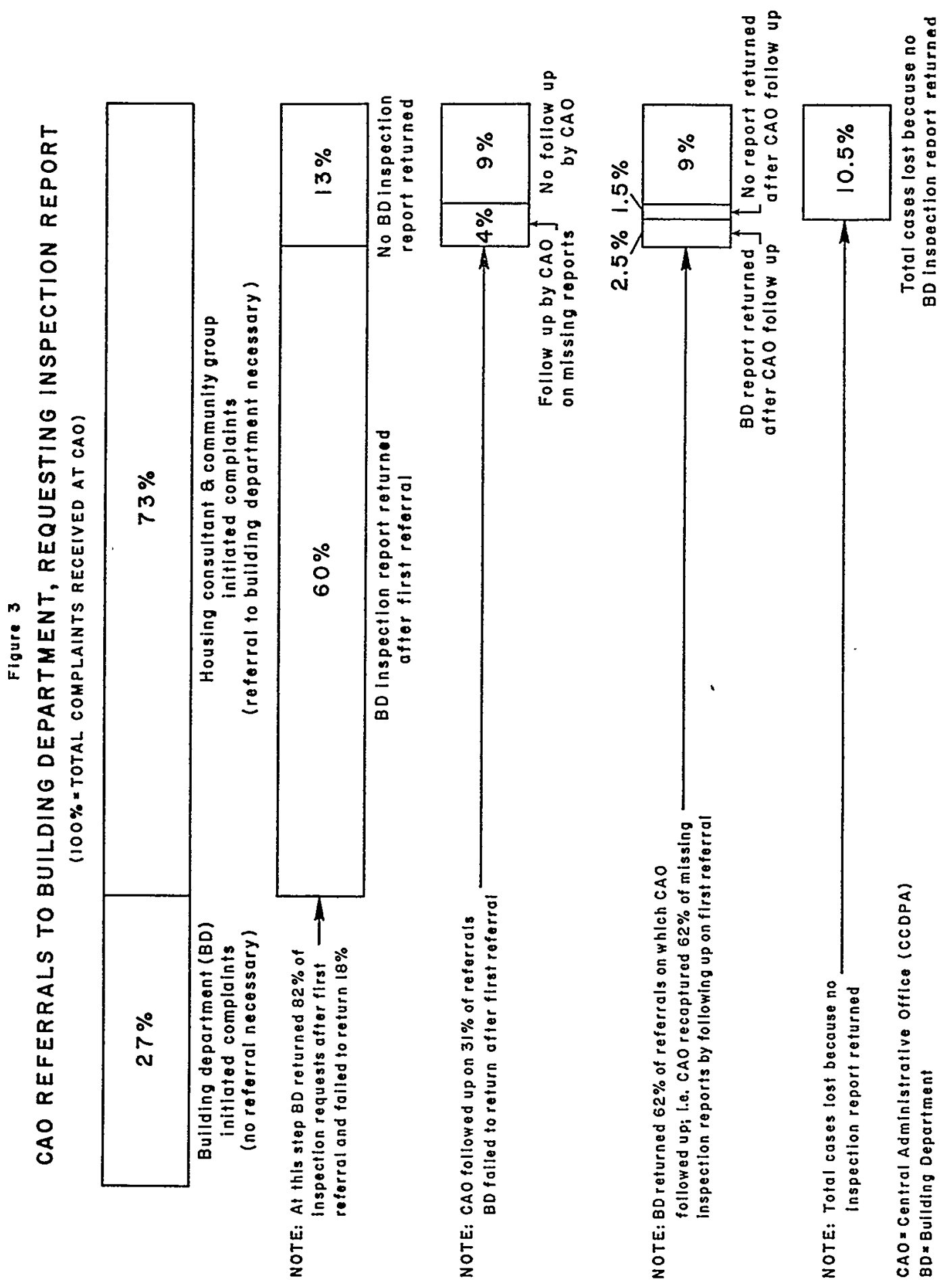


community groups or a copy of the Chancery Court complaint for those cases initiated by the Building Department. ${ }^{110}$ The CAO then requests the housing consultants to submit a breakdown of the number of public aid recipients living in the building. It would be possible at this point to make an evaluation of the seriousness of violations and to eliminate from the enforcement process those buildings which do not have serious violations. Instead, a CAO clerk merely lists the buildings having violations ${ }^{111}$ and sends these lists every two months ${ }^{112}$ to the housing consultants in each district office. ${ }^{113}$

As Figure 4 indicates, the CAO should have requested breakdown reports in 87 per cent of the cases in the sample; ${ }^{114}$ the CAO made

110 See note 38 and accompanying text supra.

111 Id.

112 According to a CAO staff member, this two-month interval has been eliminated and breakdowns are now requested immediately upon receipt of either the Building De. partment report or the Chancery Court complaint. Statement of Mr. Morton Miller, Ad. ministrative Assistant, Bureau of Housing, CCDPA, May 29, 1970. This is apparently the result of the new operating procedure, effective May 8, 1970, which provides that upon receipt of the Building Department report listing violations the CAO is to telephone the housing consultant "to determine if there is any current information that would affect the withholding proceedings." Bulletin 70.24, supra note 35 , at 2.

113 Neither the operating manuals in effect in 1968-69 nor the one presently in effect, supra note 35, delineates a standard breakdown procedure for the housing consultants to follow. Consequently, housing consultants return breakdown reports either by telephone or by memorandum. There is no detailed procedural outline for the clerk at the CAO to follow in sending and receiving the breakdown reports. Further, many housing consultants appear to conduct another inspection of the building before returning their report and make a written recommendation as to withholding. However, in the majority of cases the housing consultants did not file a later withholding recommendation with the breakdown, and it can be assumed that by simply reporting the number of recipients, they are agreeing with the CAO decision to withhold.

Because of the lack of a formal breakdown procedure, information on breakdowns was in a confused state for 1968. In fact, there was often no indication of whether the CAO had ever requested a breakdown from the housing consultant. For those breakdowns requested during 1969, the records were in order.

In all cases where rent was withheld, we assumed that a breakdown had been requested and received by the $\mathrm{CAO}$, even though there might have been no records indicating this. The mere fact that the CAO had information regarding the number of recipients in a building is sufficient evidence to establish the request of a breakdown report and its return by the district office.

114 Housing consultants filed breakdown reports with the housing survey report in $3 \%$ of the sample cases. However, the staff of the CAO contends that breakdown reports are filed with the housing survey reports in the vast majority of cases. Interview with the CAO staff, supra note 38. Our data does not support this contention, but, on the contrary, it confirms the statement of one housing consultant that only when a housing consultant wishes to speed up the withholding process does he include a breakdown with the housing survey report. Housing Consultant Taylor said the reason for the failure to file breakdown reports was the delay between the filing of the housing survey report and the actual withholding. Many public aid recipients remain in one location for only a short period of time and a breakdown report sent too early often becomes obsolete. Interview with Housing Consultant, supra note 34 . 

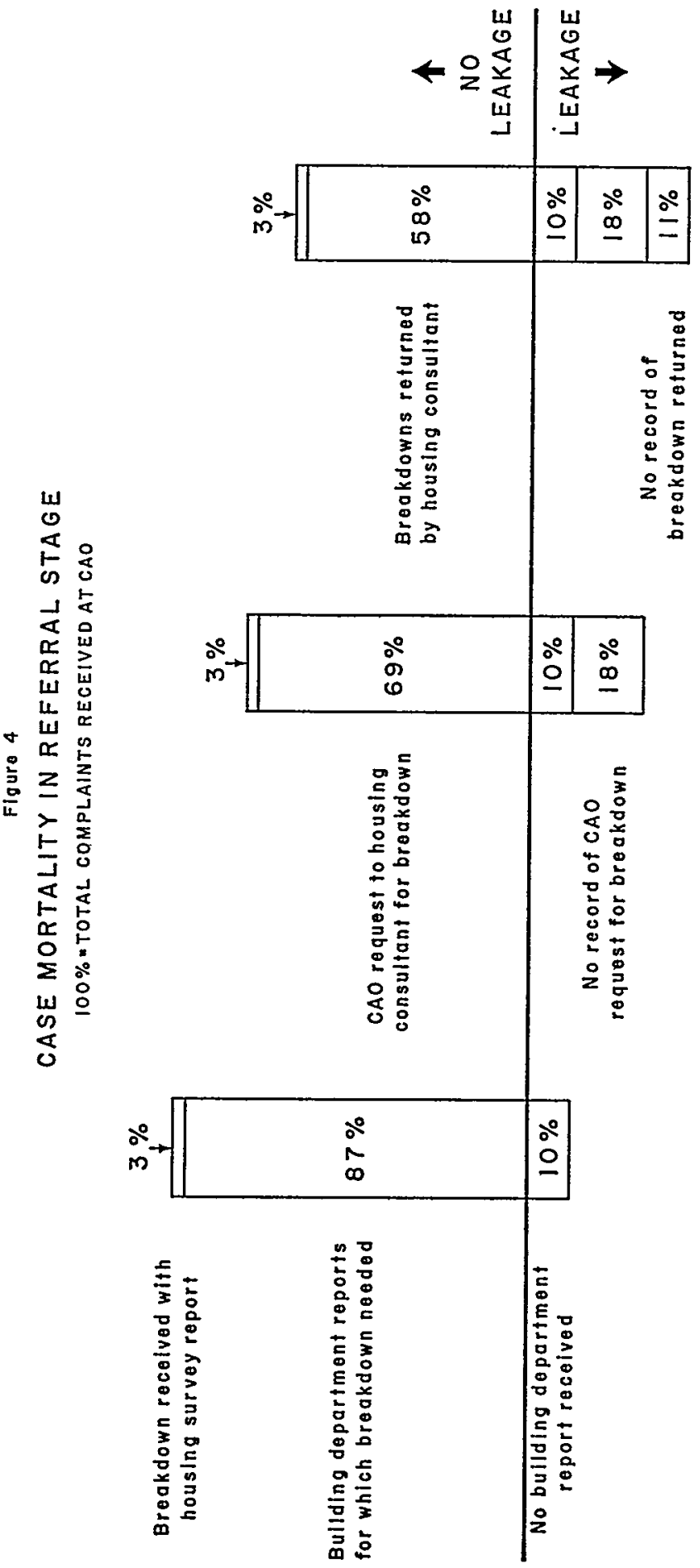
such requests in only 69 per cent of the cases. Thus, 18 per cent of all cases were dropped from the enforcement procedure by the failure of the $\mathrm{CAO}$ to request breakdown reports. ${ }^{115}$

The breakdown step involves the return of the breakdown report by the housing consultant. If the breakdown report is not returned the withholding process ends, since there is no follow-up on these cases. ${ }^{116}$ The housing consultants returned these reports in 58 per cent of the total cases, or in more than 80 per cent of the cases for which the CAO requested breakdowns. However, because the housing consultants failed to return breakdown reports, the CAO took no further action in 11 per cent of the cases. ${ }^{117}$

Figure 4 provides a brief summary of the referral stage. Thirty-nine per cent of all cases were eliminated from the enforcement process during this stage. This loss resulted from three factors: (1) the failure of the Building Department to forward the requested inspection reports to the CAO during the inspection step (10\%); (2) the failure of the $\mathrm{CAO}$ to request breakdown reports during the request step (18\%); and (3) the failure of the housing consultants to file the breakdown reports during the breakdown step ( $11 \%$ ). No cases were lost during the initiation step. The greatest amount of leakage occurred within the CCDPA itself, where 29 per cent of the original complaints were lost.118

115 Because of the confusion in the breakdown records for 1968, there is a possibility for error in the figure for the number of cases for which the CAO did not request a breakdown report; however, we believe the combined figure for failure by the CAO to request breakdowns and the failure by housing consultants to return breakdown reports is an accurate record of the overall performance of the CCDPA in the breakdown report process.

116 The reader should compare the lack of a systematic follow-up procedure on referrals made to the Building Department for inspections during 1968-69 with the lack of any follow-up procedure for breakdown requests forwarded to the housing consultants. See notes 108-9 and accompanying text supra.

117 The data indicates that complaints initiated by the Building Department receive different treatment by the CCDPA during the breakdown report process. During this period the case mortality rate of Building Department initiated cases is higher than that for housing consultant initiated cases. The records indicated that the CAO requested breakdowns in $82 \%$ of all housing consultant initiated cases for which breakdowns were needed, but in only $71 \%$ of the Building Department initiated cases where breakdowns were needed. Likewise, the housing consultants returned breakdowns in a higher percentage of the cases which they initiated. Breakdowns were returned in $89 \%$ of the housing consultant initiated cases for which the $\mathrm{CAO}$ requested breakdowns, whereas breakdowns were returned in only $69 \%$ of the Building Department initiated cases for which breakdowns were requested.

118 The staff members at the GAO contend that most problems in the administration of the rent withholding program were caused by the Building Department's failure to return inspection reports. Interview with CAO staff, supra note 38. At the 1968 Hearings, 
(b) Case mortality in the withholding stage. The withholding stage of administration, outlined in Figure 1, begins when the housing consultant returns the breakdown report to the CAO. The CAO received breakdown reports for 61 per cent of the cases in the sample. These reports indicated recipient occupancy in almost three-fourths of these

Figures

CASE MORTALITY IN WITHHOLDING STAGE

$100 \%=$ TOTAL COMPLAINTS RECEIVED AT CAO

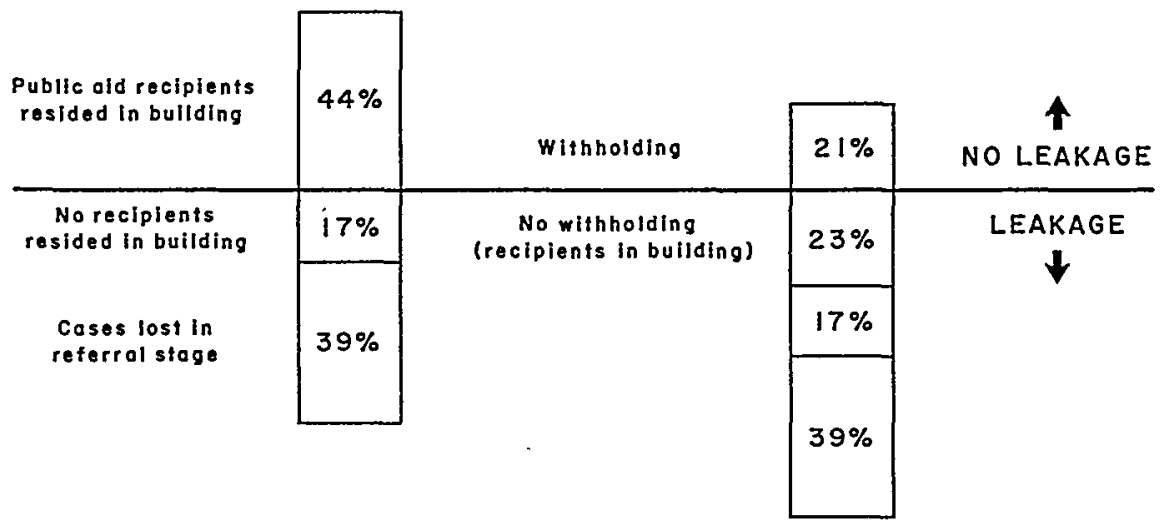

buildings, or in 44 per cent of the total buildings. Thus, 17 per cent of the original cases were eliminated from the enforcement process because no public aid recipients lived in the buildings.

The GAO had sufficient information to withhold in the 44 per cent of the total cases left after completion of the breakdown report procedure. However, the CAO withheld in only 21 per cent of the total cases, or in less than one-half of the cases for which breakdowns were received indicating recipient occupancy.

The reasons for not withholding in these cases are numerous. In 43 per cent of the nonwithholding buildings which housed public aid recipients, or 10 per cent of the total cases, the status of the building changed so as to prevent withholding. Table 1 indicates the causes of these changes in status. The failure to withhold in the remaining 57 per cent of the nonwithholding buildings which housed public aid re-

the CCDPA presented evidence that the Building Department had failed to return inspection reports in over 2200 cases which the CAO had referred to it during the previous three years. However, the data shows that for all cases initiated in 1968 only $10 \%$ were lost because of the failure of the Building Department to conduct an inspection. In other words, the CAO received as much cooperation from the Building Department on the return of inspection reports as it received from its own housing consultants on the return of breakdown reports. 
TABLE 1

Causes of Nonwithrolding in Buildings Containing Rectpient Occupants AT THE TIME OF THE BREARDOWN REPORT

\begin{tabular}{|c|c|c|}
\hline Cause & $\begin{array}{l}\text { Per Cent of } \\
\text { Total Sample }\end{array}$ & $\begin{array}{l}\text { Per Cent of } \\
\text { Buildings Housing } \\
\text { Recipients at Time } \\
\text { of Breakdown not } \\
\text { Withheld Against }\end{array}$ \\
\hline \multicolumn{3}{|l|}{$\begin{array}{l}\text { Demolished, abandoned } \\
\text { or fire-gutted before }\end{array}$} \\
\hline \multicolumn{3}{|l|}{$\begin{array}{l}\text { Public aid recipients } \\
\text { moved before withholding }\end{array}$} \\
\hline effected & 3.5 & 15 \\
\hline \multicolumn{2}{|l|}{ No withholding pending } & 2 \\
\hline Compliance before withholding & 5 & 22 \\
\hline \multirow[t]{2}{*}{$\begin{array}{l}\text { Administrative problems in } \\
\text { obtaining notification letters }\end{array}$} & 13 & 57 \\
\hline & 23 & 100 \\
\hline
\end{tabular}

cipients, or 13 per cent of the total cases, was due to administrative problems in obtaining notification letters. ${ }^{119}$

Of the 21 per cent of the buildings which finally reached withholding, nearly two-thirds either remained substandard at the end of the period studied or were removed from the housing market by demolition, abandonment or fire. ${ }^{120}$ Only 7.5 per cent of all buildings were brought into compliance with code standards after withholding and before the end of the period studied.

(c) Conclusions as to case mortality. The data reveals five important facts regarding case mortality: (1) 79 per cent of all cases were eliminated from enforcement during the administrative process. (2) 67 per cent of this mortality was due to preventable administrative problems, while 33 per cent was due to nonpreventable factors, such as lack of recipient occupancy or changes in the status of the buildings. (3) While significant leakage was expected in the withholding stage, due to changes in status, leakage in the referral stage, almost equalling that in withholding, was surprisingly high. (4) The Building Department was more efficient in returning inspection reports during the referral stage than anticipated. (5) Leakage in the breakdown report process, administered solely by the CCDPA, was significantly greater than expected.

8. Delay in Enforcement. This section examines delay in both the

110 For a more complete explanation, see notes $153-8$ and accompanying text infra. 120 Since the study ended at an arbitrary point in time, it is likely that some additional buildings will later reach compliance. See Table 5 and accompanying text infra. 
referral and withholding stages of the enforcement process. The median time required for either withholding or compliance before withholding was 156 days, ${ }^{121}$ and only 4 per cent of the cases reaching this point did so within 60 days. ${ }^{122}$

(a) Delay in the referral stage. The referral stage, outlined in Figure 1, can be divided into four time periods. ${ }^{123}$ The initiation period is the time between initial inspection ${ }^{124}$ by the housing consultant and referral of the housing survey report to the Building Department. ${ }^{125}$ During this period the housing consultant and his investigators prepare the housing survey report. After the landlord is notified that his building is substandard, the report is sent to the CAO, which files the report and forwards a copy to the Building Department. The median time required for completion of this process was 10 days. At the end of 15 days, more than 80 per cent of the cases had completed the process, but after 51 days, 5 per cent still had not been referred to the Building Department. ${ }^{126}$

121 In many respects it is inaccurate to speak of an "average number of days" because of the nature of the distribution. Therefore, we will concentrate on median time, which is a more meaningful figure.

122 The Department contends that in an emergency situation it can withhold rents within a two-week period. Interview with Victor Spallone, supra note 44. Either there were no emergencies in our sample or the Department is unable to achieve this goal. There were no cases that required less than 40 days.

123 See note 100 supra.

124 When the Building Department is the source of the complaint, the date of initiation represents the day on which the CCDPA receives a copy of the Chancery Court complaint. When the housing consultants are the source, the date of initiation represents the day on which the inspector completes his report, which is usually the date of inspection.

The day on which the district office first receives a complaint on a particular building was not available; however, most inspections are performed by the housing consultants within the month the complaints are received. For example, during 1968 the housing consultants for all of Cook County had on hand at the first of each month an average of 99 pending inspections, and received an average of 3351 new inspection requests each month. Of this combined average of 3450 inspections to be performed, the housing consultants disposed of an average of 3347 . Housing Consultants Monthly Report, supra note 32.

Also, in those cases which were initiated by the filing of a housing survey report, we obtained the number of days which elapsed between the completion of the report by the inspector and the review of the report by the housing consultant. There was no record of the date on which the housing consultants referred the housing survey reports to the CAO. For the vast majority of cases, however, this should be an automatic referral with no appreciable time lag. See note 35 and accompanying text supra. One housing consultant informed us that there is usually a two-day delay in mail delivery between the CAO and the districts. Interview with Housing Consultant, supra note 34.

125 The date available for the referral of the housing survey report to the Building Department was the day on which the CAO sent the request for a report to the Building Department. The initiation step does not include cases initiated by the Building Department since no further inspection is required in those cases because the copy of the Chancery Court complaint contains an official list of the code violations in the building. 128 In $75 \%$ of the cases initiated by the housing consultant, the number of days which 
Once the housing survey report has been referred to the Building Department for inspection, the case enters the second step in the referral stage-the inspection period. ${ }^{127}$ - This period measures the time required by the Building Department to return an inspection report to the GAO.

The statute requires that upon request by the CCDPA, the Building Department "shall promptly investigate and report its finding" to the CCDPA. ${ }^{128}$ The median time required by the Building Department to return the inspection report was 21 days. At the end of one month the Building Department had returned reports in 63 per cent of the cases for which reports were eventually returned, and at the end of two months reports had been returned in 84 per cent..$^{129}$

Once the GAO receives the building inspection report, it must wait for a breakdown report on the number of public aid recipients living in the building before it can withhold.130 This third step, or request period, is the time the $\mathrm{CAO}$ requires to request breakdown reports. ${ }^{131}$ The median delay in the request procedure was 5 days. At the end of 15 days requests had been made in 78 per cent of the cases, but 50 or more days were required in 4 per cent of the cases.

The final step in the referral stage is the breakdown report period..$^{132}$ During this step the housing consultant determines the number of public aid recipients living in the building. His investigation involves either a personal visit to the building or contact with the building's caseworker. ${ }^{133}$ The median time housing consultants required to obtain

elapsed between the completion of the housing survey report by the investigator and the review by the housing consultant was only five days or less. Usually the housing consultant merely checks the investigators housing survey report to see if it is filled out properly. Occasionally the housing consultant will inspect the building himself to check on the investigators' diligence. Interview with Housing Consultant, supra note 34.

127 See note 100 supra.

128 ILL. REv. STAT. ch. 23, § 11-23 (1969) (emphasis added).

129 The Building Department often does not make a new inspection, but instead simply forwards the results of an earlier inspection. In $20 \%$ of the sample cases the Building Department returned inspection reports based on inspections which were conducted before the referral of the housing survey report to the Building Department, and in $8 \%$ of the sample cases the inspection was conducted as much as three months before the report was requested. This procedure allowed the Building Department to improve its percentage of cumulative return: in $90 \%$ of the cases where prior inspection information was used, inspection reports were returned to the CAO within 30 days; where the inspection date followed the referral date, the rate of return was $54 \%$ within 30 days.

130 For 1968 , information on the breakdown report process was confused and often no dates were available for either the date on which the request was sent to the district office or the date on which the report was returned to the CAO or both. For those breakdowns requested during 1969, the records were organized and complete.

131 See note 100 supra.

$132 I d$.

133 In 1969 the CAO initiated a new system for the breakdown report process which 
the breakdown and return it to the CAO was 20 days. At the end of 40 days 74 per cent had been returned, and all but 2 per cent were returned within 90 days. Thus, although the Building Department inspection took an average of 35 days, as compared with 29 days in the breakdown report step, the median for both was almost identical (see Table 2). ${ }^{134}$

The receipt by the CAO of the breakdown report from the district office marks the end of the referral stage. The median time required for cases to reach this point was 78 days and the average time required was 92 days. Although 30 per cent of the cases which completed the referral stage did so within 40 days, 24 per cent took more than 120 days. ${ }^{135}$

Those cases which eventually reached withholding moved more rapidly through the referral stage than those which dropped out of the enforcement process (see Table 2). The average time required for a withholding case to complete this stage was 80 days, as compared with 98 days for nonwithholding cases. The medians were 65 and 81 days, respectively. As shown in Table 2, the most significant cause of the disparity between withholding and nonwithholding cases was the actions of housing consultants during the breakdown report step.

(b) Delay in the withholding stage. During the withholding stage, outlined in Figure 1, all action is centered in the CAO, which must prepare and mail the notification letter. If the return receipt on the certified mail is received, signed by the addressee or his agent, the CAO authorizes withholding 10 to 12 days after mailing. ${ }^{136}$

In those cases which reached either withholding or compliance before withholding, the median time from the receipt of the breakdown report

probably lengthened the time required for this step. This system involved a two-month time lag, whereby the district offices would receive lists of buildings only every two months. Beginning May 8, 1970, the CAO began requesting breakdowns immediately after receiving the Building Department reports. See note 112 supra.

134 These figures would seem to rebut the Building Department's reputation for poor performance, a reputation widely expressed in personal comments of CAO staff members and in testimony delivered by the CCDPA at the 1968 Hearings, supra note 28.

It would appear that the performances of the Building Department and the Department's housing consultants are approximately the same with regard to both the time required to submit the requested report and the proportion of reports actually returned. See Figure 4 supra. Although Building Department initiated cases had a higher proportion of drop-outs during the breakdown report process than housing consultant initiated cases, see note 117 sippra, the data indicates that the speeds at which the housing consultants return the breakdown reports are virtually identical. The average time required for a Building Department initiated case to be processed at this step was 28 days as compared with 30 days for housing consultant initiated cases, and the median was 20 days for both.

135 See Figure 4 supra, which provides a summary of case mortality in the referral stage. 136 See note 41 and accompanying text supra. 
to the actual withholding ${ }^{137}$ or compliance before withholding ${ }^{138}$ was 78 days. Only 10 per cent of the cases completing this stage did so within 40 days, and 28 per cent required over 120 days. ${ }^{139}$

The time between withholding and compliance involves factors outside the CCDPA's control, and will therefore be considered separately. ${ }^{140}$

(c) Conclusions as to delay. Because comparably fewer tasks are involved in the withholding stage, one might expect this stage to require significantly less time than the referral stage. A comparison of the time required in each of these stages, however, reveals that the average number of days required in the referral stage is 4 less than in the withholding stage and that the medians are identical (see Table 2).

The period of time required for a case to move from initiation to withholding was surprisingly long. As Table 3 shows, only 17 per cent of the cases which completed the process did so within 90 days, and after 180 days 34 per cent still had not completed the process. ${ }^{141}$

187 The actual date on which the caseworker deleted the rents from the public aid recipient's check was not available. The only withholding date available was the day on which the CAO sent the order to withhold to the district office. How rapidly the rents were actually deleted from the check would depend on the district office procedure and efficiency. Further, since the checks are prepared at the State Comptroller's office in Springfield, an order to withhold rents sent from the CAO at the end of June would not result in withholding until the August monthly public aid check. The checks are prepared alphabetically in groups, e.g., all checks for persons whose last names end in A through $D$ are prepared at a certain time. If the change in the monthly budget which reflects the rent deletion arrives at the Comptroller's office after the preparation of the check, then the withholding must wait another month. Interview with CAO staff, supra note 38 .

138 The day on which the landlord brought his building up to code standards was the compliance date. However, the day on which the landlord actually completes his repairs was not available, and the date used for compliance was the date on which the housing consultant inspected and found the building to be up to standard. This could have occurred either before the withholding notice had been mailed, after the notice of withholding had been given but before the actual withholding, or after withholding. There were few instances where compliance occurred before the withholding and most information available on compliance involved cases in which withholding actually took place.

139 Again, as was discussed in connection with the breakdown report, see note 117 supra, it is interesting to note the apparently different treatment given cases originating in the Building Department and those originating in the CCDPA's district offices. If we take the time period from the receipt of a Building Department inspection report, or in cases initiated by the Building Department from the receipt of the Chancery Court complaint, to the actual withholding of rents or compliance before withholding, we find that the average time for housing consultant initiated cases to be processed was 121 days, whereas the average for Building Department initiated cases was 126 days. However, the median for housing consultant initiated cases which completed this process was 111 days while the same figure for Building Department initiated cases was 97 days. Also interesting to note is that whereas $18 \%$ of those housing consultant initiated cases which completed this process had moved through the time period within 60 days, no Building Department initiated cases had been processed within this time.

140 See Table 5 and accompanying text infra.

141 As one would have expected, the Building Department initiated cases reached with- 
TABLE 2

ANALysis OF DeLAY

\begin{tabular}{|c|c|c|c|c|c|c|}
\hline \multirow[b]{2}{*}{$\begin{array}{l}\text { Stage and Steps } \\
\text { in Administration } \\
\text { of Withholding } \\
\text { Statute }\end{array}$} & \multicolumn{3}{|c|}{$\begin{array}{l}\text { AVERAGE No. of } \\
\text { Days Required to } \\
\text { Complete Stage } \\
\text { and/or Steps }\end{array}$} & \multicolumn{3}{|c|}{$\begin{array}{c}\text { MEDIAN No. of } \\
\text { Days Required to } \\
\text { Complete Stage } \\
\text { and/or Steps }\end{array}$} \\
\hline & $\begin{array}{c}\text { All } \\
\text { Cases }\end{array}$ & $\begin{array}{l}\text { With- } \\
\text { holding } \\
\text { Cases }\end{array}$ & $\begin{array}{l}\text { Non- } \\
\text { with- } \\
\text { holding } \\
\text { Cases }\end{array}$ & $\begin{array}{c}\text { All } \\
\text { Cases }\end{array}$ & $\begin{array}{l}\text { With- } \\
\text { holding } \\
\text { Cases }\end{array}$ & $\begin{array}{l}\text { Non- } \\
\text { with- } \\
\text { holding } \\
\text { Cases }\end{array}$ \\
\hline $\begin{array}{l}\text { Entire withholding } \\
\text { process: initiation } \\
\text { to withholding } \\
\text { or compliance }\end{array}$ & - & 167 & - & - & 156 & - \\
\hline Referral Stage & 92 & 80 & 98 & 78 & 65 & 81 \\
\hline $\begin{array}{l}\text { a. Initiation step } \\
\text { b. Inspection step } \\
\text { c. Request step } \\
\text { d. Breakdown }\end{array}$ & $\begin{array}{l}15 \\
35 \\
15 \\
29\end{array}$ & $\begin{array}{l}16 \\
38 \\
11 \\
27\end{array}$ & $\begin{array}{l}14 \\
34 \\
15 \\
30\end{array}$ & $\begin{array}{r}10 \\
21 \\
5 \\
20\end{array}$ & $\begin{array}{r}7 \\
20 \\
5 \\
13\end{array}$ & $\begin{array}{r}11 \\
21 \\
5 \\
21\end{array}$ \\
\hline Withholding Stage & - & 96 & - & 一 & 78 & - \\
\hline
\end{tabular}

TABLE 8

OVERALL ADMINISTRATION: INITIATION TO WITHHOLDING

\begin{tabular}{lccccccc}
\hline Number of & & & & & & & \\
$\quad$ Days & $0-90$ & $91-120$ & $121-150$ & $151-180$ & $181-210$ & $211-240$ & $241-330$ \\
$\begin{array}{l}\text { Frequency } \\
\text { Cumulative }\end{array}$ & $17 \%$ & $18 \%$ & $7 \%$ & $24 \%$ & $10 \%$ & $7 \%$ & $17 \%$ \\
Frequency & $17 \%$ & $35 \%$ & $42 \%$ & $66 \%$ & $76 \%$ & $83 \%$ & $100 \%$ \\
\hline
\end{tabular}

Median $=156$ days

$100 \%=$ those cases where either compliance was achieved before withholding (but after letter sent) or rents were withheld ( $24 \%$ of the sample cases).

\section{B. An Evaluation of Enforcement}

This section examines the limited nature of the CCDPA's enforcement scheme and the general effectiveness of withholding as a means to induce landlord compliance.

1. An Evaluation of Enforcement-Limited Enforcement. Since the

holding much quicker than those cases initiated by the housing consultants because there is no need to refer the complaints to the Building Department for inspection, since the Chancery Court complaints, which list the violations, are based on recent inspections. The CAO needed an average of 172 days to move a housing consultant initiated case from the date of initial inspection to either withholding or compliance before withholding, whereas an average of only 150 days was required for Building Department initiated cases. To complete the entire cycle from initiation to withholding or compliance before withholding, the median for housing consultant initiated cases which reached the final step. was 168 days and the comparable figure for Building Department initiated cases was 149 days. 
CCDPA withheld in only 21 per cent of the cases originally brought to its attention, the rent withholding program as presently administered may be appropriately characterized as a limited enforcement scheme. Limited enforcement may be preferable to full enforcement if either: (1) the enforcing agency has limited resources, or (2) the additional costs of increased enforcement (including demolition) outweigh the incremental benefits (primarily compliance) of greater enforcement. A limited enforcement scheme, to be effective, must be based on objective standards for determining which cases require withholding. If cases are eliminated from the enforcement process because of administrative problems, arbitrary decision making or random selection, enforcement will be less effective than it might otherwise be.

An analysis of the reasons for case mortality in the administrative process reveals that the CCDPA's limited enforcement scheme is primarily a result of administrative problems rather than of a conscious policy to restrict the scope of enforcement. The CAO failed to withhold in 79 per cent of the original cases. Twenty-six per cent of the cases dropped from the enforcement process because either no recipient resided in the building or there was a change in the status of the building. ${ }^{142}$ Since the CAO could not prevent the exclusion of these cases under any system, they will be disregarded for the purposes of this analysis. By focusing on the remaining 53 per cent, however, we can attempt to determine the extent to which case mortality was due to administrative problems and the extent to which it was due to a conscious policy of restricting enforcement. Moreover, if such a conscious policy exists, this analysis may reveal what standards, if any, are applied..$^{143}$

Ten per cent of the cases were lost in the Building Department by its failure to return the required inspection reports. ${ }^{144}$ Although the

142 The change in status referred to was due to either (1) no recipients resided in the building $(17 \%)$, (2) the recipients who did reside in the building moved before withholding was effected $(3.5 \%)$, (3) the building burned down, was abandoned or was demolished before withholding $(1 \%)$, or (4) the landlord repaired the building before the rents were withheld (5\%). See Table 1 and Figure 5 supra.

143 It should be noted that the CAO staff consistently maintained that the only standard applied was that expressed in the statute: ". . . a condition dangerous, hazardous or detrimental to life or health ... ." ILl. REv. STAT. ch. 23, § 11-23 (1969). Interview with CAO staff, supra note 38 . However, this standard was of no help in determining why this $53 \%$ of the total sample dropped from the enforcement process.

144 Since we did not make an in depth study of the Building Department, we do not know why these cases were lost. It is unlikely that the Building Department found no violations and thus did not return a report. See note 108 and accompanying text supra. The 1968 Hearings, which were held to investigate alleged improprieties of the Building Department in the enforcement of the building code, may provide an answer. See notes 67 \& 118 supra. 
CAO had no direct control over this loss, it could have significantly reduced it by persistently following up when reports were not returned. ${ }^{145}$ It is unclear why the CAO followed up in some cases and not in others.

Forty-three per cent of the cases were lost within the CCDPA itself. The CAO's records indicate that 18 per cent were lost because it failed to request breakdown reports from the housing consultants. ${ }^{146}$ There is no indication that the CAO intentionally decided to eliminate these cases from enforcement. In fact, as a result of the automatic breakdown procedure followed by the $\mathrm{CAO},{ }^{147}$ potential withholding cases did not even come to the attention of staff members until after breakdowns were filed. Thus, it is likely that this leakage was due to either administrative inefficiency ${ }^{148}$ or lack of manpower. ${ }^{140}$

Housing consultants eliminated 11.5 per cent of the cases by failing to return breakdown reports (11 per cent) and status reports ( 0.5 per cent). The CAO made no systematic attempt to follow up in these cases. ${ }^{150}$ Since the CAO staff did not enter the process until after breakdowns were received, the failure to follow up was probably due to administrative problems within the CAO. On the district office level, administrative problems undoubtedly caused some of this leakage, but it is possible that in some cases the housing consultants decided not to file reports. ${ }^{151}$ If such decisions were in fact made, the standards used, if any, are unknown..$^{152}$

145 See note 109 and accompanying text supra.

146 See note 115 and accompanying text supra.

147 See notes $111-7$ and accompanying text supra.

148 One case initiated by the Building Department involved a modern apartment complex which obviously housed no public aid recipients. It might be possible that other cases involving buildings in which it was known that no public aid recipients resided were eliminated. However, if this occurs regularly, our interviews with CAO staff members did not reveal it. Further, over one-half of the cases for which breakdowns were not requested were initiated by the housing consultants, and on cases originating in the district offices, mere street addresses could not be used to determine whether public aid recipients lived in the building.

149 The CAO asserted at all times that more personnel were needed to enforce the statute. Interview with CAO staff, supra note 38 .

150 See note 116 and accompanying text supra.

151 For example, the housing consultant may have known that no recipients lived in the building because of the quality of the building or the neighborhood.

152 We did not study the district office procedures in depth, but rather focused on decision making in the CAO. However, there is no indication from the CAO files that the individual housing consultants followed any formalized or uniform standards in exercising their discretion. There was definitely no CAO policy memorandum to guide them. It may be that housing consultants negotiated with landlords concerning repair and secured landlord cooperation. This is unlikely for most of the dropouts, however, because in only a few of the cases for which no breakdown was received was the building eventually repaired. Housing consultants failed to return breakdown reports in 23 sample cases. In 
The CAO failed to withhold in 13 per cent of the cases even though Building Department inspection reports and breakdown reports were available. According to the CAO, a delay in the printing of new notification letters ${ }^{153}$ caused all but 3 per cent of this loss. ${ }^{154}$ Since this delay lasted until January, 1970, the CAO maintains that it withheld in only the worst cases in $1969.155 \mathrm{It}$ is unclear how it determined which were the worst buildings. ${ }^{156}$ Since it did withhold in some cases in 1969, it

response to our questionnaire, housing consultants reported having made an inspection more recent than the first in only 13 cases. Of these 13 cases, 4 buildings were standard after the second inspection.

However, one would think that if a housing consultant had in fact negotiated with the landlord and secured cooperation, he would have filed a report with the CAO. One CAO staff member stated that the failure to return a breakdown report or a report on the condition of the building is pure inefficiency on the part of the housing consultant. Interview with CAO staff, supra note 38.

153 A form notification letter is used to inform landlords of withholding. See note 40 and accompanying text supra. New letters were required because of the appointment of a new CCDPA director (January 20, 1969) and the passage of an amendment to the statute (effective July 24,1969 ) relating to the $20 \%$ penalty provisions. See note 46 and accompanying text supra.

154 The data supports this claim. First, all of the cases comprising this $10 \%$ of the sample fell within the permissible dates. In other words, the CAO did not receive the Building Department inspection report and the breakdown report until 1969; therefore, when the case was ripe for withholding, the proper forms were not available. Second, if this was evidence of something more, such as a policy of restricting the scope of enforcement, it was peculiar to 1969 . We found no such mass failure to withhold by the CAO for cases which were initiated in the first half of 1968. Further, it is interesting to note that rents were withheld in $21 \%$ of the total cases in the sample-18\% in 1968 and $3 \%$ in 1969. Since the withholdings in the sample should have been approximately equally divided between the two years, this tends to substantiate the claim that in 1969 rents were withheld from only a small number of buildings.

155 Interview with CAO staff, supra note 38.

156 The files for withholding and nonwithholding buildings in 1969 did not indicate any differences in the conditions of the buildings in each of these two groups. The data on the quality of housing conditions was inconclusive on this point, however. A major problem in accumulating such data was that the breakdown reports usually reported the total number of occupants and total rental grant for all families in the building, but did not report the actual number of dwelling units in such buildings. Table A attempts to compensate for this lack of information by use of that information which was available.

Table A shows that the rental grant per recipient was higher in the nonwithholding buildings than in the withholding buildings. This difference could result from several variables: (1) the number of rooms in the apartment; (2) housing conditions; (3) occupancy rates and (4) maintenance services. A study conducted by the CCDPA indicates that whereas rental grants are larger in buildings in sound condition, grants are also larger in those buildings with more than one person per room, with the poorest maintenance services and with the most code violations. CCDPA, CASTLEs of THE POOR: A STUDY of Housing Conditions of Public Aid Families in Cook County, Ilinnois 160-2 (1969) [hereinafter cited as CASTLES OF THE POOR]. 
is difficult to understand why it could not withhold in all cases. ${ }^{157}$ Moreover, it is even more difficult to understand why the CAO did not attempt to avoid the problems caused by the printing delay by simply obtaining the necessary letter through some alternate means.

Finally, in 3 per cent of the cases the CAO received both the Building Department report and the breakdown report in adequate time to withhold in 1968, but did not withhold. ${ }^{158}$ No action was taken on these

\begin{tabular}{|c|c|c|c|}
\hline & $\begin{array}{l}\text { TABLE A } \\
\text { Rental grant } \\
\text { per recipient* }\end{array}$ & $\begin{array}{l}\text { Public aid } \\
\text { recipients per } \\
\text { dwelling unit** }\end{array}$ & $\begin{array}{c}\text { Rental grant } \\
\text { paid per } \\
\text { dwelling unit*** }\end{array}$ \\
\hline \multicolumn{4}{|l|}{ NONWITHHOLDING } \\
\hline $\begin{array}{l}\text { Buildings which were } \\
\text { known to be substandard } \\
\text { and to house public aid } \\
\text { recipients, but from which } \\
\text { no rents were withheld }\end{array}$ & $\$ 20.69$ & 1.87 & $\$ 38.71$ \\
\hline \multicolumn{4}{|l|}{ WITHHOLDING } \\
\hline $\begin{array}{l}\text { Buildings which had } \\
\text { rents withheld }\end{array}$ & $\$ 17.14$ & 1.34 & $\$ 23.04$ \\
\hline $\begin{array}{l}\text { - Rental grant per recipien } \\
\text { * Public aid recipients per } \\
\text { dwelling unit }\end{array}$ & $\begin{aligned} t= & \text { total public aid } \\
& \text { number of pub } \\
= & \text { total public aid } \\
& \text { total dwelling } \\
& \text { units in the bu } \\
& + \text { nonrecipient } \\
= & \text { total rental gra } \\
& \text { total dwelling } \\
& \text { units in the bu } \\
& + \text { nonrecipient }\end{aligned}$ & $\begin{array}{l}\text { recipients in the } \\
\text { units in the build } \\
\text { ilding = public aic } \\
\text { occupied). } \\
\text { nts for the entire } \\
\text { units in the build } \\
\text { ilding = public aid } \\
\text { occupied). }\end{array}$ & $\begin{array}{l}\text { d divided by total } \\
\text { the building. } \\
\text { uilding divided by } \\
\text { ng (total dwelling } \\
\text { recipient occupied } \\
\text { uilding divided by } \\
\text { ng (total dwelling } \\
\text { recipient occupied }\end{array}$ \\
\hline
\end{tabular}

The ratio of public aid recipients per dwelling unit was greater in the nonwithholding buildings than in the withholding buildings. This ratio represents either a larger number of recipients residing in one unit or many recipient occupied units in the building. Since the monthly rental grants are based on the number in the household and also on the number of rooms in the units, id. at 166, the most likely explanation for the larger rental grant per recipient is larger apartments rather than buildings in better condition. In fact, if the recipient per dwelling unit ratio represents a large number of recipients per dwelling unit, the indications are that the units are in poorer condition. Id. at 42.

157 The CAO staft said that when the form letter problem first arose, it refrained from withholding because it did not believe it could legally do so without the proper letter. Later, it decided that since the old form letter did state that the withholding would be done pursuant to the statute and any amendments thereto, withholding could be legally effected. It was, however, still reluctant to withhold in all possible cases. Interview with CAO staff, supra note 38 .

158 It should be noted that this $3 \%$ consisted of two cases, one of which was under 
cases until 1969, at which time the problems with the form letter prevented withholding.

In sum, it seems that administrative problems were the predominant cause of the limited nature of the CCDPA's enforcement scheme. Moreover, in those instances where cases might have been intentionally eliminated from enforcement, there is no indication that either the CAO or the housing consultants applied objective standards in making such decisions.

2. An Evaluation of Enforcement-Effectiveness of Withholding. While the CCDPA's limited enforcement scheme leaves much to be desired, particularly in the way of standards, the withholding of rents appears to be a relatively effective means of coercing landlords to repair. A comparison between withholding buildings and nonwithholding buildings housing public aid recipients reveals that compliance was achieved in 36 per cent of the withholding buildings as opposed to only 22 per cent of the nonwithholding buildings. Since both groups of buildings were in approximately the same condition, ${ }^{159}$ the higher rate of compliance for withholding buildings indicates that withholding is an effective tool for inducing compliance.

A second factor to be considered is the fact that the 36 per cent compliance rate is essentially open ended, since some withholding cases which did not reach compliance by the conclusion of this study may later do so. This is likely because the median time required for compliance after withholding was 240 days (see Table 5). For example, 45 per cent of the 1968 withholding cases reached compliance by the time the study was concluded, whereas none of the 1969 withholding cases had done so. This factor is important for evaluating the general effectiveness of withholding, but may not be relevant for examining its effectiveness relative to nonwithholding, for the 22 per cent compliance rate for nonwithholding cases is also open ended.

A third factor to be considered in determining the effectiveness of withholding is the cause of noncompliance. Withholding failed to induce compliance in 64 per cent of the withholding cases. In 5 per cent of these cases, compliance was not achieved because the building was either demolished or destroyed. ${ }^{160}$ The loss of the remaining 59 per cent

a Chicago Dwelling Association (CDA) receivership. One CAO staff member stated the CCDPA did not withhold from buildings which it knew to be in CDA receivership ". . since this would constitute action by the County Department against the efforts of a city department." Statement of Mr. Morton Miller, Administrative Assistant, Housing Bureau, CCDPA, May 29, 1970. There are no records indicating that a CAO staff mem. ber chose not to withhold on a building for that reason.

159 This is inferred from the fact that demolition rates for the two groups were virtually identical. See notes 167-8 and accompanying text infra.

160 See note 167 and accompanying text infra. 
appears to be due to one of two factors: either the recipient moved soon after withholding, or the landlord simply refused to comply even though his rents were being withheld. Since 98 per cent of the withholding buildings still had recipient occupants three and one-half months after withholding, the first factor is probably not a significant cause of noncompliance. ${ }^{161}$ Thus, it appears that the predominant cause of noncompliance was the landlord's weighing the cost of repair against the cost of lost rents and deciding that it would be cheaper not to repair. This proposition is supported by Table 4, which indicates that the compliance rate increased as the rent withheld per dwelling unit increased. ${ }^{162}$ However, as Figures 6 and 7 illustrate, this correlation is

TABLE 4

LEVERAGE IN WITHHOLDING

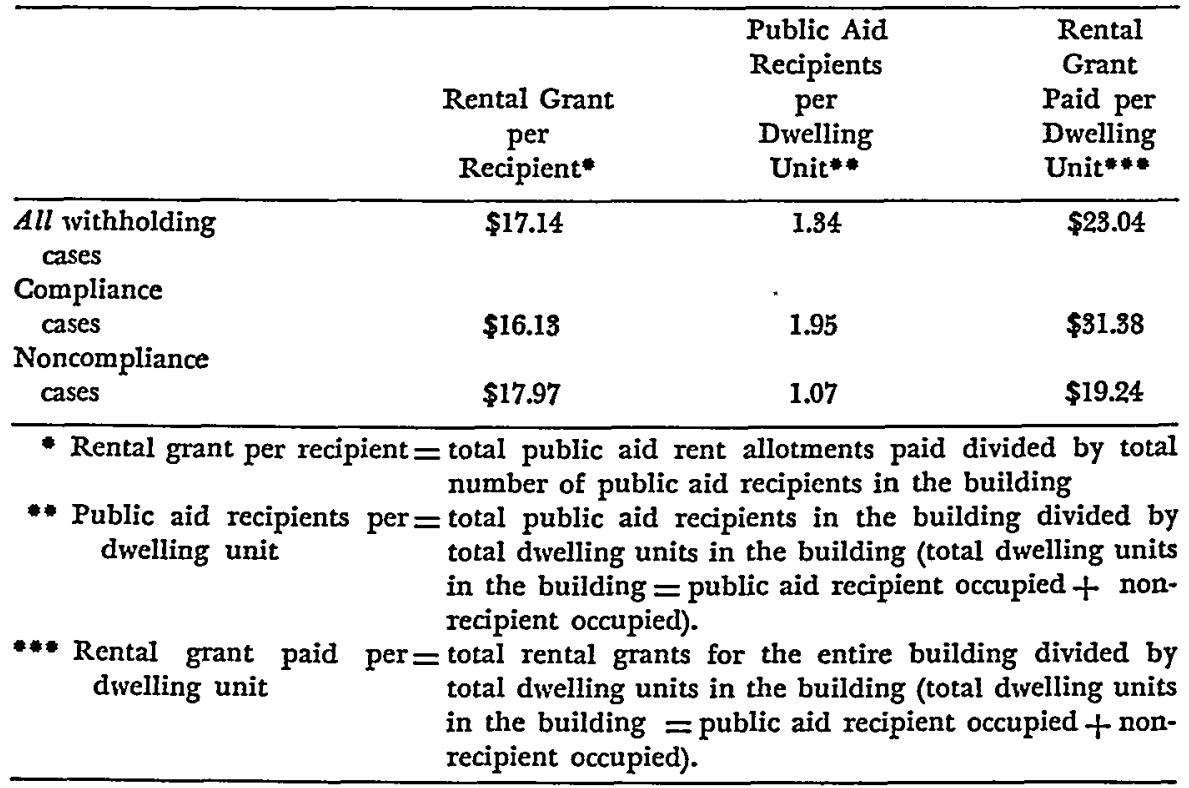

161 See note 91 and accompanying text supra.

162 The rental grant per recipient was lower for the compliance buildings than the noncompliance buildings. At the same time the recipient per unit ratio was almost twice as high in the compliance cases. These factors together indicate that the apartments have approximately the same number of rooms and the same number of recipients per unit because rental grants are dependent on the number in the household and the number of rooms in the dwelling unit. CASTLES OF THE POOR, supra note 156, at 166 . In fact, since the rental grant per recipient is greater in the noncompliance cases, the data might indicate that units in the noncompliance cases are slightly larger. Id. Thus, the recipient per unit figure for the compliance cases would represent not a concentration of recipients in dwelling units but a concentration of recipient occupied units in the building. The rental grant per dwelling unit reflects the greater amount of monetary leverage exercised against the landlord in the compliance cases as contrasted with the noncompliance cases.

There appeared to be a positive correlation between the length of time required to 
Figure 6

\section{LEVERAGE AS A FACTOR OF RENTAL GRANT \\ PAID PER DWELLING UNIT*}

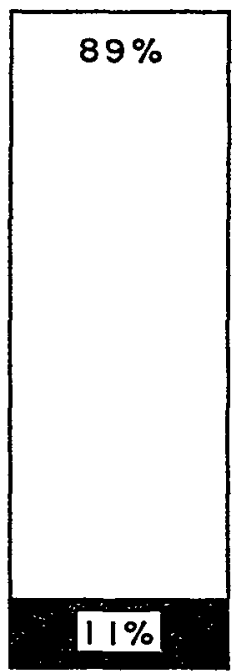

UNDER \$16

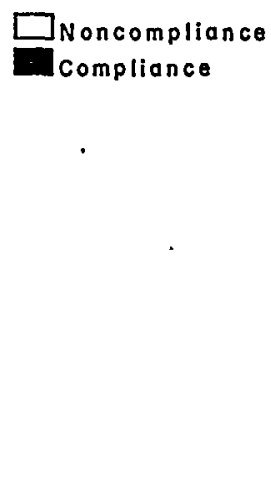

RENTAL GRANT PAID PER

DWELLING UNIT

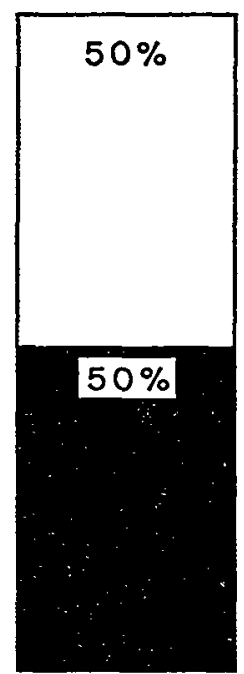

$\$ 16$ OR MORE
$100 \%=A L L$ WITHHOLDING CASES

IN SAMPLE WITH RENTAL GRANT

PAID PER DWELLING UNIT UNDER $\$ 16$
$100 \%=$ ALL WITHHOLDING CASES
IN SAMPLE WITH RENTAL GRANT
PAID PER DWELLING UNIT \$16
OR MORE

- Rental grant paid per dwelling unit = total rental grants for the entire building divided by total dwelling units in the building.

not complete. It appears that there is a threshold level, which may be expressed as either 1.5 recipients per dwelling unit or $\$ 16$ rental grant

achieve compliance after withholding of rents and the leverage factor. We averaged the public aid recipient per unit ratio for compliance cases in groups arranged by the time required to achieve compliance after withholding. Assuming from the above discussion that the public aid recipient per unit ratio represents concentrations of public aid recipient units in a building, we believe that a correlation between leverage and the required time for compliance is shown. For example, for those cases which reached compliance within 180 days after withholding, there was an average of approximately 3 recipients per dwelling unit, while those cases requiring over 180 days had an average of approximately 1.8 recipients per dwelling unit.

Further, a policy of withholding from buildings with a greater number of recipient occupied units would not appear to increase the rate of demolition among withholding buildings. For the two withholding buildings in the sample which were demolished, the public aid recipient per unit ratios were 1.3 and 35 respectively. Although inconclusive the figures would tend to indicate that there is no correlation between the amount of leverage and demolition. 
Figure 7

LEVERAGE AS A FACTOR OF THE NUMBER

OF RECIPIENTS PER DWELLING UNIT*

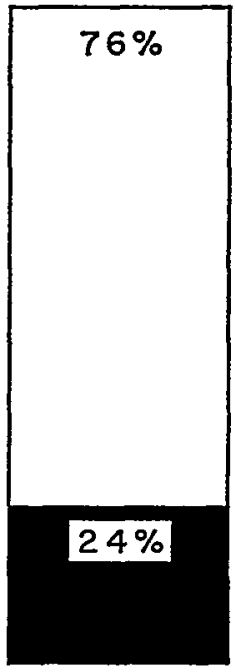

1.5

OR LESS
NUMBER OF RECIPIENTS PER DWELLING UNIT

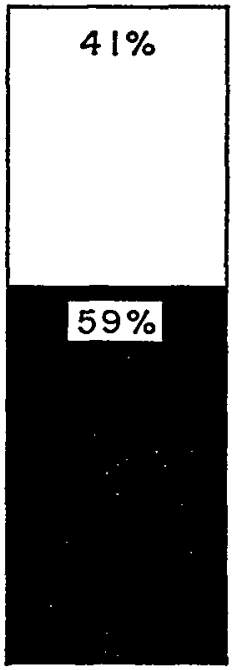

MORE

THAN 1.5 .
$100 \%=A L L$ WITHHOLDING CASES IN SAMPLE WITH LESS THAN 1.5 RECIPIENTS PER DWELLING UNIT

\section{$100 \%=A L L W I T H H O L D I N G$ CASES IN SAMPLE WITH 1.5 OR MORE RECIPIENTS PER DWELLING UNIT}

- Number of recipients per dwelling unit = total number of recipients in building divided by total number of dwelling units in building.

per dwelling unit, below which compliance is rarely achieved. This indicates that landlords are refusing to repair because the cost of repair is significantly greater than the cost of lost rents. Above the threshold level withholding often induces compliance; but above this level the compliance rate remains relatively constant-it does not increase proportionately to increased withholding. This indicates that some factor other than relative cost is being considered. The data collected in this study does not reveal the nature of this additional factor. It is clear, however, that at least below the threshold level the relative costs of withholding and repair are considered by landlords, and that below this level compliance is unlikely. Thus, it can be concluded that rent withholding, by itself, necessarily fails to induce compliance in a significant number of cases where the cost of compliance exceeds the withholding penalty. 
This deficiency may be eliminated to some extent by the 20 per cent penalty provision enacted in $1969,{ }^{163}$ which would substantially increase the cost of noncompliance. The effects of this provision cannot be measured by this study, however, for the CCDPA did not begin implementing it until after the study was concluded. ${ }^{184}$

A fourth indication of the effectiveness of rent withholding is the speed with which withholding can be effected. The median time required for a case to move from initiation to withholding was surprisingly high-156 days (see Table 3). While the necessity of conforming to statutory procedural requirements caused some of this delay, the predominant cause was administrative problems. ${ }^{165}$ Thus, the withholding statute should not necessarily be judged ineffective on this ground. Significantly, 17 per cent of the cases reaching withholding did so within 90 days.

A final measure of the effectiveness of rent withholding may be the amount of time required for compliance after withholding. The median time required for compliance after withholding was 240 days, although as Table 5 shows, 36 per cent of the cases reaching compliance did so within 150 days. The use of the 20 per cent penalty provision might significantly reduce the time required for compliance. Since a comparison of the time required for compliance in a withholding enforcement

103 See note 46 and accompanying text supra.

104 The CCDPA did not begin implementing the provision in earnest until early 1970 because it did not receive the proper form letter until then. See notes 153-7 and accompanying text supra. The probable effect of the provision would be to raise the cost of noncompliance, thereby lowering the threshold level so as to enable a higher compliance rate.

165 During the withholding stage the explanation for much of the delay was the procedure followed in 1968 and 1969 of withholding in groups, and not withholding as each case arrived at that stage. The Department justifies this procedure on two grounds. First, mass processing of withholdings is more efficient, and, because of the limited staff, this procedure must be followed. Second, withholding on a great number of buildings at the same time gives the low income housing problem more publicity.

Another aspect of delay involved in the withholding stage occurred in the process of notifying the landlord of withholding action. The order to withhold rents was sent to the district office within 10 to 12 days after the letter was mailed to the landlord in all but $11 \%$ of the cases in which rent was withheld. In this $11 \%$ of the cases the landlords claimed that repairs had been made, and the CAO delayed withholding action until a later report could be obtained from the housing consultant. In all of these cases, rent was eventually withheld and the average delay between the initial letter and the actual withholding was 72 days.

Further, in $15 \%$ of the cases in which rents were withheld, two letters had to be sent to notify the landlord because the first was returned undelivered. In these cases there was an average delay of 92 days between the initial letter and the actual withholding.

In addition, there are some delays built into the statutory requirements. For example, the requirement that the Building Department verify violations adds an average of 35 days to the withholding process. Also, the statute allows the landlords a ten-day grace period after notification of withholding and before withholding may be instituted. 
TABLE 5

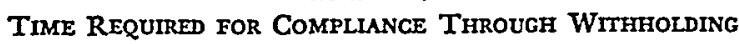

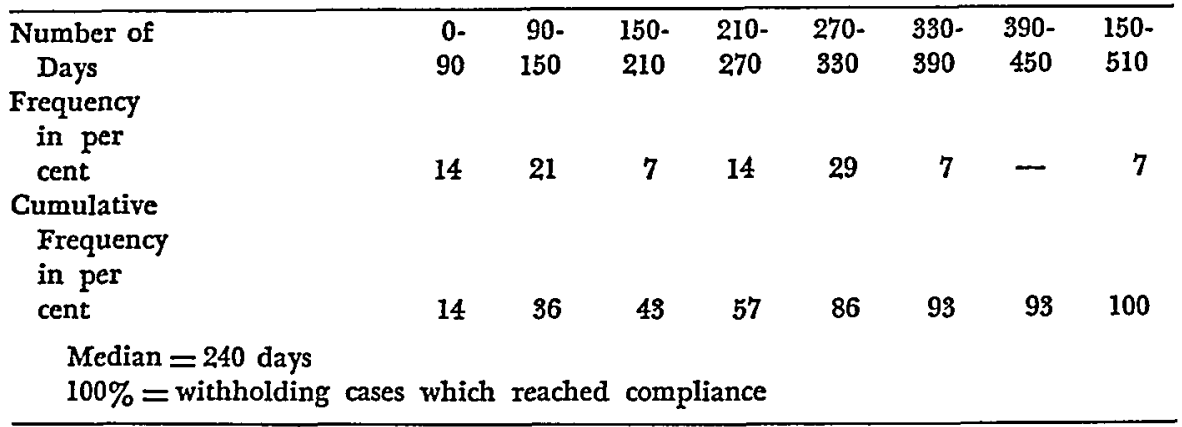

scheme with the time required by other code enforcement techniques, such as those used by the Building Department, cannot be made in this study, it cannot be determined whether this time is inordinately long. However, in light of the fact that rent withholding is intended to alleviate conditions endangering life or health, it does seem that compliance through withholding is unduly slow.

\section{Criteria for Efficient Enforcement}

While the CCDPA's withholding program appears to be a more effective means of inducing landlord compliance than enforcement without withholding, the program has achieved only limited effectiveness. The CCDPA withheld in only 21 per cent of the cases, and compliance was achieved in only 7.5 per cent. The absence of a conscious policy of restricting the scope of enforcement indicates that the CCDPA attempted to withhold in all cases meeting the statutory requirements for withholding, but that it failed to achieve this goal because of administrative inefficiency and lack of adequate manpower. Thus, the cases in which the CCDPA eventually did withhold did not necessarily contain the most serious violations and were not necessarily the most likely to result in compliance.

The withholding program may be made more effective by either: (1) a significant influx of additional manpower to enable the CCDPA to withhold in all cases meeting the statutory requirements for withholding; or (2) the adoption of a conscious policy of restricting the scope of enforcement coupled with a reallocation of existing manpower to eliminate administrative leakage and the formulation of objective standards for determining which cases require withholding.

In deciding whether full enforcement (alternative 1) or limited enforcement (alternative 2) is more desirable for Cook County, the competing costs and benefits of full enforcement must be weighed. The 
two most significant costs of full enforcement are the increased administrative expenses and the possible shrinkage of the low income housing market. ${ }^{168}$ The first of these costs, increased administrative expenses, would be due to the additional manpower that would be required at both the CAO and district office levels if the present administrative problems are to be avoided.

More important is the possible effect of full enforcement on the low income housing market. The study indicates that the rates of demolition for withholding buildings and nonwithholding buildings housing public aid recipients are almost identical. ${ }^{107}$ Thus, it can be presumed that both groups of buildings were in approximately the same condition and that the condition of housing has more causal relation to demolition than does withholding. ${ }^{168}$

$180 \mathrm{It}$ has long been recognized that one of the dangers of strict enforcement of city building codes is the possibility that the low income housing market may be sharply reduced. Note, Enforcement of Municipal Housing Codes, supra note 11, at 802. A strictly enforced rent withholding program might have the same effect as strict enforcement of the building codes. By denying a landlord income from the building which is substandard, the landlord must either raise the rents charged to tenants in order to cover the cost of repair, or demolish or abandon buildings.

In Chicago, the low income housing situation has reached crisis proportions.

Demolition of low income housing units has by far exceeded the number of new units constructed. Programs of rehabilitation for substandard structures have not been sufficiently accelerated to meet the growing demands of the community for decent low income housing. Slum clearance programs have bulldozed many blighted areas, but frequently the land reclaimed through that work is used for the construction of highways, universities, commercial and business structures and luxury high-rise apartments. These problems are by no means peculiar to Cook County, and slum clearance across the country frequently means slum moving. CASTLES OF THE POOR, supra note 156, at 1.

167 The rates of demolition were $5 \%$ for withholding buildings and $4 \%$ for nonwithholding buildings.

168 If there was a selection process in which rents were withheld only from buildings in relatively better condition and if the CCDPA now begins a program of full enforcement, in which it also withholds against buildings in worse condition, it is possible that the demolition rate will increase. Although the Department maintains that it withholds against all substandard buildings which come to its attention without regard to varying degrees of quality among these buildings, the data neither confirms nor denies this. See note 156 supra.

However, in cases where it admits to having exercised discretion in the selection of cases for withholding (e.g., the 1969 withholdings, see note 155 and accompanying text supra), the GAO states that rents were withheld against what it considered to be the buildings in the worst condition. Although again the data does not confirm or deny this, see note 156 supra, if it is true, then the present demolition rate might not be affected by full enforcement of the statute.

Further, it should be noted that it is possible that demolitions may also increase if the Department has refrained from withholding against landlords who it fears will abandon their buildings if the sanction is applied. Our data does not indicate whether the nature and reputation of the landlord played any role in the decision whether to withhold. The Department maintains that it withholds against all landlords whose substandard buildings have come to its attention, and, in fact, prides itself in its successes in forcing "slum. 
However, full enforcement may have two tangential effects on the low income housing market that are not as susceptible to quantitative analysis. First, expanded coverage may lead to increased landlord discrimination against public aid recipients. Thus, recipients may find themselves unable to obtain adequate housing. Second, since landlords often increase rent after compliance, thereby pricing the building out of the low income market, increased enforcement may indirectly result in shrinkage of the low income housing market.

The benefits to be gained from full enforcement might be quite substantial. During the study, the CCDPA withheld in 336 cases and achieved compliance in only 120. A full enforcement scheme, during the same period, could have resulted in 1194 withholdings and 430 compliances. ${ }^{169}$

The increased effectiveness of a full enforcement scheme, which would result in a more rapid improvement in the conditions of low income housing, seems to outweigh the incremental costs of such a scheme. However, if full enforcement cannot be instituted because additional funds are not forthcoming or the effect on the low income housing market would be too severe, the CCDPA's present limited enforcement scheme may be greatly improved by a concentrated effort to eradicate the administrative problems and the arbitrary elimination of cases from the enforcement process. The objective should be to eliminate unexplained case mortality and to conserve the CCDPA's limited resources for use in those cases where compliance is most needed or most probable.

One method to control the administrative problems would be to designate a group of CAO staff members as coordinators, whose sole job would be to keep close watch on the flow of cases and to prevent unnecessary leakage. Some of the procedural problems could be avoided by the adoption of a new detailed operating manual, ${ }^{170}$ instructing staff

lords" out of business (although at the same time recognizing that, unfortunately, this latter result may decrease the low income housing supply).

109 Of the original sample of 204 cases, withholding was effected in $21 \%$, or 42 cases, and compliance was achieved in $36 \%$ of the withholding cases, or 15 cases. Projecting these figures over all cases initiated in 1968, withholding would be reached in 336 cases and landlords would comply in 120.

Under a full enforcement scheme, all leakage could be eliminated except that which is due to either recipient nonoccupancy (10\%) or change in status of building (17\%). Thus, withholding could be effected in $73 \%$ of the cases, or 1194 cases. Projecting the compliance rate of $36 \%$ to these cases, compliance could be reached in 430 cases. Moreover, since the compliance rate is open ended, compliance might be achieved in an even greater number of buildings. See text accompanying note 159 supra.

170 Apparently, the CCDPA periodically issues new operating manuals after procedural problems arise. The most recent manual is Bulletin 70.24, supra note 35, which may solve some of the problems discussed. We are suggesting, however, that the CCDPA conduct 
members and housing consultants as to exactly what procedures are to be followed. One solution which is already underway is the adoption of a computerized filing system, ${ }^{171}$ which should help the Department make more efficient use of its resources. ${ }^{172}$

Along with the elimination of the administrative problems, the GAO should adopt objective standards for determining which cases should be dropped from the enforcement process. In formulating these standards, at least three factors should be considered. First, since withholding is aimed at protecting the health and safety of recipients, priority should be given to buildings containing the most serious violations. Second, the reparability of the building should be considered. If the building is not structurally sound, withholding is unlikely to induce lasting repairs. Third, the Department should consider the leverage that could be exerted against the landlord. The study indicates that withholding in buildings with relatively few recipient occupants is unlikely to induce compliance. ${ }^{173}$ Thus, the Department should effect withholding in those cases where compliance is most probable.

Given the Department's limited resources, it seems that a balancing of these three factors, on a case by case basis, would allow the CCDPA to make the most effective use of the withholding statute. The important point is that the Department should develop both standards and procedures which would insure the most effective use of its resources.

a comprehensive study of the withholding process with the goal of formulating procedures to eliminate unjustifiable leakage and delay.

171 Telephone conversation with Victor Spallone, Housing Bureau Chief, CCDPA, June 12,1970 .

172 In addition, a study is now underway at the CCDPA concerning the feasibility of using the receivership law, ILL. REV. STAT. ch. 24, § 11-31-2 (1969), in conjunction with rent withholding in order to use withheld rents for rehabilitation of noncompliance buildings.

173 See notes $160-4$ and accompanying text supra. 